\title{
EL CABEÇATGE, UN DESCONEGUT SERVEI APROVAT A LES CORTS VALENCIANES DE 1301-1302
}

\author{
Vicent Baydal Sala ${ }^{1^{*}}$ \\ Institució Milà i Fontanals, CSIC de Barcelona
}

\section{RESUMEN}

La expedición llevada a cabo por Jaime II de Aragón contra su hermano Federico II de Sicilia entre julio de 1298 y septiembre de 1299 generó unas enormes deudas para la Corona, agravadas por las primeras campañas de conquista del reino castellano de Murcia. Por ello, el rey trató de que sus súbditos contribuyeran al saneamiento de sus finanzas a través de los servicios aprobados en diversas reuniones de Cortes que tuvieron lugar, sucesivamente, en Cataluña en 1299-1300, en Aragón en 1300 y 1301, y en Valencia en 1301-1302. Este artículo analiza las características de aquellos servicios, con especial atención al concedido en las Cortes valencianas, recaudado a través de un impuesto de capitación denominado «cabeçatge».

Palabras clave: Fiscalidad, Cortes, Reino de Valencia, Catalunya, Aragó, Jaime II, Siglo XIII, Siglo XIV.

1 Doctor en Historia. Departamento de Estudios Medievales. Institució Milà i Fontanals. Consejo Superior de Investigaciones Científicas (CSIC). 08001. Barcelona. C.e: vicentbaydal@gmail.com

* Abreviatures emprades: ACA (Arxiu de la Corona d'Aragó), C (Cancelleria), reg. (registre), RP (Reial Patrimoni), MR (Mestre Racional), s. (sou barcelonès o valencià, considerats amb la mateixa equivalència), s.j. (sou jaquès), d. (diner barcelonès o valencià), d.j. (diner jaquès). D'una altra banda, hem indicat la data dels documents quan és rellevant i coincideix o és cronològicament propera a l'acció explicada. 


\section{ABSTRACT}

The expedition carried out by James II of Aragon against his brother Frederick II of Sicily from July 1298 to September 1299 generated a huge debt to the Crown, made worse by the first campaigns to conquer the Castilian kingdom of Murcia. Therefore, the king tried that his subjects contribute to get his finances into shape through the services approved at various meetings of Parliament that took place successively in Catalonia in 1299-1300, in Aragon in 1300 and 1301, and in Valencia in 1301-1302. This article discusses the characteristics of those services, with special attention to that given at the Valencian Parliament, raised through a poll tax called «cabeçatge».

Keywords: Taxation, Parliament, Kingdom of Valencia, Catalonia, Aragon, James II, $13^{\text {th }}$ century, $14^{\text {th }}$ century.

Les Corts celebrades per Jaume II i els estaments del regne de València en 1301-1302 han restat pràcticament ignotes per a la historiografia valenciana. En aquest sentit, allò que hom n'ha dit fins el moment procedeix exclusivament dels textos jurídics recollits en el llibre de privilegis de la ciutat de València, és a dir, del conjunt de privilegis aprovats en l'assemblea, amb data de 21 de gener de 1302, i d'una disposició posterior, del 14 de febrer de $1304^{2}$. Tanmateix, ara podem aportar noves informacions sobre el context d'aquestes Corts, les seues dates exactes de celebració i el servei que s'hi aprovar. Cal destacar, a més a més, que aquest és el primer donatiu conegut en què la noblesa del regne de València, d'origen majoritàriament aragonès, acceptà participar, atès que mantenia un dur enfrontament amb la monarquia a causa de la disputa per l'aplicació dels Furs d'Aragó al territori valencià ${ }^{3}$.

2 N'han parlat, més o menys extensament: J. MARTínez Aloy, La Diputación de la Generalidad del reino de Valencia, València, 1930, p. 78-82; A. GARCIA, Furs de València, Barcelona, 1970, vol. I, p. 16; S. ROMEU, «Catálogo de Cortes valencianas hasta 1410», Anuario de Historia del Derecho Español, XL (1970), p. 581-607; V.L. SimÓ, Les Corts valencianes. 1240-1645, València, 1997, p. 91-95; Mª. R. MUÑOz POMER, «Cortes y fronteras de Valencia en el siglo de Alcañices (1250-1350)», Revista da Faculdade de letras- Historia. II Série, XV (1998), p. 753-772; P. LóPEZ EluM, Los orígenes de los Furs en Valencia y las Cortes en el siglo XIII, València, 2001, p. 90-91; V. GARCIA EDO, Furs de València, Barcelona, 2002, vol. IX, p. 53-54

3 És ben poc el que se sap sobre els donatius anteriors del segle XIII, ja que no s'ha fet una recerca exhaustiva en els fons de l'Arxiu de la Corona d'Aragó. Vegeu: P. LóPEZ Elum, Los orígenes de los Furs en Valencia y las Cortes en el siglo XIII, cit.; J. MARTínEZ Aloy, La Diputación de la Generalidad del reino de Valencia, cit. Sobre l'enfrontament per la qüestió foral: S. ROMEU, «Los Fueros de Valencia y los Fueros de Aragón: jurisdicción alfonsina», Anuario de Historia del Derecho Español, 42 (1972), p. 75-115. 


\section{EL CICLE DE CORTS DE 1299-1302 A LA CORONA D'ARAGÓ}

Els poc més de dos anys compresos entre finals de 1299 i començaments de 1302 enquadren una sèrie de celebracions successives de Corts de les diferents unitats polítiques de la Corona d'Aragó, convocades per la monarquia amb l'objectiu principal d'eixugar els enormes deutes contrets a causa dels seus dos principals afers bèl-lics del moment: els atacs a Sicília i el projecte d'apropiació territorial del regne de Múrcia.

En juny de 1295 Jaume II havia signat amb el papa Bonifaci VIII i Carles II de Nàpols la pau d'Anagni, mitjançant la qual el rei aragonès renunciava als seus drets sobre Sicília i es comprometia a lluitar contra el seu germà Frederic en cas que aquest es negués a retre l'illa. Així, lliurat momentàniament dels afers sicilians, Jaume II envaí el regne de Múrcia en abril de 1296 en connivència amb l'infant Alfons de la Cerda, que entrà simultàniament a Castella amb la intenció d'arrabassar el tron al jove Ferran IV. Lany següent, durant la primavera de 1297, el monarca aragonès fou comminat a complir l'obligació d'intervenir contra Frederic II de Sicília; abans de fer-ho, però, l'hivern de 1297-1298, realitzà una segona campanya militar contra els dominis castellans de terres murcianes i, a continuació, a partir de juliol de 1298, lluità al costat dels Anjou durant vora quinze mesos a les mars sicilianes. Finalment, en octubre de 1299 Jaume II tornà definitivament a la península Ibèrica, tot iniciant una sèrie de reunions de Corts per alleugerir els ingents deutes que havia acumulat al llarg d'aquelles campanyes bèl-liques" ${ }^{4}$.

Així, l'hivern de 1299-1300 se celebraren unes Corts catalanes a Barcelona, durant les quals el rei manifestà deure fins a 6.000 .000 s., empenyorats

4 Vegeu els moviments del monarca durant aquests anys a: J. ZURITA, Gestas de los reyes de Aragón, Saragossa, 1984 [ed. original: 1578]; J.D. GARRIDO, La conquesta del sud valencià i Múrcia per Jaume II, Barcelona, 2002; J.M. DEL ESTAL, Itinerario de Jaime II de Aragón (1291-1327), Saragossa, 2009, p. 128-194. D’una altra banda, en realitat el monarca tractà d'evitar la celebració de Corts en tornar a la península, ja que inicialment convocà un Consell General a Lleida amb la presència dels principals magnats i representants urbans de Catalunya, Aragó i València. Tanmateix, els súbdits degueren protestar la decisió, puix uns dies després el rei hagué de convocar tres Consells diferenciats per a cada territori. Finalment, a més a més, el primer que s'havia de celebrar, el català, acabà transformant-se en una assemblea de Corts, ja que, segons es deia, els negocis que s'hi havien de tractar non possunt sine celebracione generalis Curie Cathalonie expediri. En conseqüència, el 24 de desembre de 1299 començaren les Corts catalanes, el que afectà a la celebració del Consell aragonès i del valencià, que quedaren posposats i acabaren per convertir-se, igualment, en reunions de Corts, celebrades al llarg dels dos anys subsegüents. Vegeu tots aquests canvis inicials a: ACA, C, reg. 265, f. 232r-233r (3-X-1299), 269r-270v (10-X-1299), 271rv (15-X1299), 272v-274v (18-X-1299), 275v-277v i 280r (5-XII-1299). 
pels recents viatges i expedicions a Roma, Nàpols i Sicília ${ }^{5}$. Per tant, l'assemblea serví per tractar de sanejar les finances reials: d'una banda, Jaume II es lliurà d'un deute heretat de 200.000 s. i 2.000 dobles d'or amb la ciutat de Barcelona a canvi de concedir-li la franquesa perpètua de quèstia, i, d'una altra banda, obtingué un servei dels estaments nobiliari i reial -l'eclesiàstic es mantingué al marge-consistent en la redempció del tribut del bovatge, taxat en $4.000 .000 \mathrm{~s}^{6}{ }^{6}$

Sobre això, gràcies a la carta de reconeixement de la venda del bovatge, sabem que la suma promesa s'havia de recaptar mitjançant un subsidi de cinc anys de duració, de març de 1300 a 1305, gestionat per comissions triades sense intervenció reial. A més a més, els diners únicament es podrien destinar a satisfer els pagaments deguts pel monarca a causa de la conquesta de Múrcia i les campanyes de Sicília, així com a l'eixugament dels deutes heretats per les guerres amb el rei de França d'època d'Alfons el Liberal'

5 ACA, C, reg. 197, f. 66r-67r (31-XII-1299). Es tracta del mateix privilegi en què s'atorgà la franquesa perpètua de quèstia a Barcelona: essemus baronibus, militibus, peditibus, corsariis et marinariis et aliis quampluribus personis obligati in maximis peccunie quantitatibus bona nostra tam mobilia quam immobilia, ascendentibus ad summam trecentarum milium librarum Barchinone. D'una altra banda, aquest elevat volum del passiu reial concorda amb un pressupost sense datar d'època de Jaume II, que tal vegada pertanya a la campanya siciliana de 1298-1299 -ja que no es correspon amb les xifres conegudes per a les guerres d'Almeria i de Sardenya, d'aquest mateix regnat. S'hi preveia l'armament de 40 galeres i 12 coques per transportar les màquines de guerra, els projectils i les viandes (vi, carn salada, formatge i més de 3 tones i mitja de farina i civada), així com un exèrcit d'unes 16.500 unitats (700 cavalls armats, amb 2 escudats i 2 ballesters per cadascun -un total de 2.800-, 10.000 escudats i ballesters més, a parts iguals, i 3.000 ballesters més, exclusivament per a les galeres). En total, doncs, l'exèrcit havia de costar un mínim de 4.170 .000 s., és a dir, 2.650 .000 s. per al pagament dels cavallers i els peons i 1.520 .000 s. per les galeres, l'armament i l'avituallament: ACA, C, Cartes reials, Jaume II, Capsa 130, núm. 33.

6 També es venien els drets d'herbatge i terratge, però el bovatge sembla ser el més important dels tres. Havia estat el primer tribut pagat per tots els estaments a la monarquia, era directe i s'hi contribuiia en funció dels béns immobles, semovents i mobles. Va nàixer com un rescat de la Pau i Treva de Déu a principis del segle XII als comtats de Cerdanya i Conflent i aquesta redempció s'incorporà posteriorment als Usatges. Per això, els monarques catalans l'exigiren a tots els estaments catalans de forma recurrent -almenys un cop durant els regnats d'Alfons el Cast i Pere el Catòlic i tres durant el de Jaume I per a les conquestes de Mallorca, València i Múrcia- fins que amb Pere el Gran s'institucionalitzà com a dret reial cobrat una vegada a l'inici de cada regnat. A partir d'aquesta venda del bovatge de les Corts de 1299-1300 restà com a tribut pagat únicament per l'estament eclesiàstic, que no el redimí fins a la segona meitat del segle XIV. Sobre tot açò, vegeu: P. ORTí, «La primera articulación del Estado feudal en Cataluña a través de un impuesto: el bovaje (ss. XII-XIII)», Hispania, LXI/3, 209 (2001), p. 967-997.

7 Pel que fa a l'empresa murciana, una llarga llista de pagaments continguda al llibre d'albarans del mestre racional de l'any 1298 traspua una important despesa acumulada, 
Alhora, s'hi explicitava el caràcter voluntari del subsidi -non ex debito set solum ex providencia et liberalitate - i el monarca renunciava a invocar-lo en el futur com a precedent impositiu. Altrament, però, desconeixem els detalls concrets de la col-lecta, que havia de portar-se a terme secundum formam et ordinacionem et modum taxatum et ordinatum in presente curia; no debades, s'hi acordà que, en concloure la recaptació, tots els documents realitzats a l'efecte serien cremats i destruïts ${ }^{8}$.

No obstant això, a la cancelleria reial s'ha conservat un registre amb disposicions relatives a la col-lecta, a través del qual sabem que el mode de tributació fou un impost indirecte, això és, una cisa quinquennal, gestionada per set comissions de dos collectors distribuides entre els bisbats de Girona, Vic, Urgell, Barcelona, Lleida, Tarragona i Tortosa -triats com a demarcació territorial- i pagada de forma generalitzada per totes les persones dels dominis nobiliaris i reials de Catalunya: richi homines, milites, cives, homines villarum et castrorum et aliorum locorum, et iudei et sarraceni et alie persone cuiuscumque dominacionis, legis aut condicionis exsisterent ${ }^{9}$. Així doncs, durant cinc anys Jaume II rebé els diners recaptats en aquells senyorius catalans a través d'una cisa, encara que en algun cas, com el del vescomte de Cardona, sabem que el rei hagué de cedir la part proporcional del donatiu: tantam quantitatem ad quantum ascendet collecta terre vestre ${ }^{10}$.

per valor de més de 200.000 s.: ACA, RP, MR, Llibres d'albarans, 621, f. 19v bis (29IV-1298). Amb tot, no podem conèixer l'abast real del cost de la guerra de Múrcia, ja que des de l'inici de 1296 fins a març de 1298 i des de juny de 1298 fins a novembre de 1306 no s'han conservat els corresponents llibres d'albarans.

8 Vegeu totes aquestes informacions sobre el donatiu a: M. SÁNCHEZ MARTínEZ i P. ORTí (eds.), Corts, parlaments i fiscalitat a Catalunya, Barcelona, 1997, doc. IV (4-II-1300), p. 27-32.

9 ACA, C, reg. 257, f. 26r-139v (6-II-1300 a 30-V-1307, la cita a: 26r).

10 El 13 de gener de 1302, mentre Jaume II celebrava Corts als valencians, envià cartes de deseiximent al vescomte de Cardona, el comte de Foix, Gastó de Bearn i Bernat de Viladomat, per incomplir allò acordat en les Corts catalanes de 1299-1300, és a dir, probablement perquè el primer es negava a traspassar la redempció del bovatge de les seues terres i els altres nobles l'ajudaven en la seua resistència. Uns dies més tard, el rei rebé notícies sobre accions armades del comte de Foix i a penes un parell de setmanes després d'haver clos les Corts valencianes, partí cap a Lleida per tal de posar setge al castell de Montfalcó, de Ramon Folc de Cardona. Finalment, el retiment es produí el 30 de març de 1302, el mateix dia en què el monarca es comprometé a donar per tèrcies anuals al noble revoltat el que es recaptés de la cisa vigent per la compra del bovatge. Vegeu per a aquests fets: J.M. DEL ESTAL, Itinerario de Jaime II de Aragón, cit., p. 234-238; ACA, C, reg. 307, f. 1rv-33v (13-I-1302 a 30-III-1302, la cita en el darrer full); C, Cartes reials, Jaume II, núms. 1642 (19-I-1302), 1303 (3-II-1302) i 1304 (4II-1302). 
A penes uns mesos després de la finalització de l'assemblea catalana, Jaume II convocà els estaments aragonesos a Corts per a l'agost de $1300^{11}$. I, segons Luis González Antón, també en aquesta ocasió el servei aprovat en l'assemblea tingué com a finalitat primordial cancel-lar els deutes reials endarrerits, bàsicament amb els nobles i cavallers d'Aragó, als quals, per l'estat de les seues finances, Jaume II no havia pogut satisfer les cavalleries d'honor almenys des de $1298^{12}$. Així les coses, les Corts atorgaren al rei un subsidi biennal que havia de ser recaptat a través de la compra forçosa per part de cada persona major de set anys d'una pesa de sal, a mesura de l'almodí de Saragossa, al preu fixat de 12 d.j. cada any. Com en el cas de Catalunya, tampoc coneixem els capítols del donatiu, però novament s'han conservat tant un privilegi reial d'indemnitat com un registre de cancelleria amb ordres referents al subsidi -que van ser parcialment publicades i estudiades pel mateix González Antón ${ }^{13}$.

Així, sabem que també el subsidi aragonès fou aprovat únicament pels estaments nobiliari i reial, romanent l'eclesiàstic fora, segons es desprèn de diverses queixes dels vassalls d'ordes religiosos, als quals el monarca reconegué que, iuxta capitula dicte Curie, eren lliures de la compra forçosa de sal ${ }^{14}$. I probablement aquesta inhibició general de l'Església era deguda al fet que Jaume II havia obtingut de Bonifaci VIII dues butlles, una de juny de 1299, que autoritzava als bisbes i abats a atorgar-li subsidis biennals per l'expedició de Sicília, i una altra, d'abril de 1300, que li concedia, també per dos anys, totes les dècimes eclesiàstiques dels seus regnes per tal de subvenir les despeses extraordinàries fetes en les campanyes a l'illa ${ }^{15}$. D'una altra banda, en el subsidi de la sal aragonès també estaven obligades a contribuir totes les persones dels senyorius implicats -els nobiliaris i els reials-, cuicumque legis et condicionis sitis, encara que s'hi exceptuaren els pobres, qui vadunt hostiari et non habent unde solveant. De més a més, es deixà clar novament que el

11 En l'interval d'unes Corts a altres, el rei hagué de celebrar a Lleida un Parlament amb el braç eclesiàstic català, que s'havia retirat de l'assemblea de 1299-1300 al-legant que certs dels seus capítols atemptaven contra l'ecclesiasticam libertatem: A. DE LA TORRE, Orígenes de la «Deputació del General de Catalunya», Barcelona, 1923, p. 40.

12 L. GonZÁlez Antón, Las uniones aragonesas y las Cortes del reino (1283-1301), Saragossa, 1975, vol. 1, p. 295.

13 Arxiu Municipal de Saragossa, Sèrie Diplomàtica, R033 (29-IX-1300); ACA, C, reg. 325, f. 1r-65v (1-X-1300 a 27-X-1303); L. GONZÁLEZ ANTÓN, Ibidem, vol. 1, p. 295298.

14 L. GonZÁlez AnTón, Ibidem, vol. 2, docs. 436 (13-XI-1300) i 438 (16-XI-1300).

15 En abril de 1303 la concessió s'allargà per al trienni subsegüent en concepte d'ajuda a la possible conquesta de Còrsega i Sardenya: F. J. Miquel Rosell, Regesta de Letras Pontificias del Archivo de la Corona de Aragón: sección Cancillería Real (Pergaminos), Madrid, 1948, docs. 304 (17-VI-1299), 306 (28-IV-1300) i 312 (20-IV-1303). 
donatiu es concedia de manera voluntària -liberaliter-, sense crear cap tipus de precedent impositiu ${ }^{16}$.

Com hem dit, l'objectiu principal era liquidar els nombrosos pagaments pendents del monarca amb els nobles i els cavallers aragonesos, i, de fet, sembla que les mateixes capitulacions del servei l'assignaven en exclusiva al pagament dels deutes reials: ad faciendum solucionum debitorum nostrorum ${ }^{17}$. Per això, el primer d'octubre de 1300, molt poc després de l'aprovació del subsidi, Jaume II ordenà conjuntament al Justícia d'Aragó i al mestre racional que, amb l'ajuda dels seus notaris, auditaren els deutes que tenia amb els vassalls del regne d'Aragó, bo i realitzant els corresponents albarans debitoris per tal de conformar un minuciós estat de comptes. D’aquesta manera, per exemple, la quantitat del subsidi recaptada als llocs nobiliaris es podria assignar directament, si el titular del senyoriu volia i tenia cobraments pendents, a la liquidació dels deutes continguts en aquells albarans ${ }^{18}$.

Pel que fa a altres aspectes tècnics de la col-lecta, sabem que la gestió de totes les salines d'Aragó passà temporalment a mans d'oficials reials, pagant com a compensació als propietaris o arrendataris la quantitat mitjana de guany que havia obtingut cada salina en els darrers tres anys ${ }^{19}$. Així, els enviats del monarca rebien i distribuien la sal entre les diverses comissions que controlaven la venda i la consegüent recaptació dels diners del subsidi ${ }^{20}$. I aquestes comissions, distribuïdes entre les juntes i sobrejuntes del regne,

16 Arxiu Municipal de Saragossa, Sèrie Diplomàtica, R033 (29-IX-1300); ACA, C, reg. 198, f. 387v-388r (3-X-1301), citat per L. GONZÁLEZ ANTÓN, Las uniones aragonesas $y$ las Cortes del reino, cit., vol. 2, doc. 491.

17 L. GonZÁlez AnTÓn, Ibidem, vol. 2, doc. 432 (17-X-1300).

18 Ibidem, docs. 426 (12-X-1300) i 431 (15-X-1300): facta summa personarum prefati richi homines, mesnaderi, milites, infanciones et alii illi tamen quibus nos in debitis teneamur, recipiunt auxilium dicti salis, si voluerint, a personis in villis suis residentibus in solutum debitorum eis peccunie quantitatum. Així, per exemple, reberen assignacions d'aquest tipus Juan Martínez de Luna (doc. 431), Aldonza, vídua del noble Fernando Sánchez de Castro (doc. 432), o Ximén de Foces (doc. 426), en el cas concret del qual s'ordenà als col-lectors diputats que: scribi faciatis omnes personas residentes in villis nobilis supradictis et, facta summa personarum predictarum, si dictus Exeminus voluerit et vos inde requisiverit, permitatis quod ipse Exeminus recipiat in solutum debitarum sibi per nos peccunie quantitatum quicquid et quantum prelibati homines in dictis villis suis residentes racione auxilii dicti salis solvere tenentur.

19 Ibidem, docs. 404 (27-IX-1300), 410 (1-X-1300) i 411 (1-X-1300). En el cas concret de les salines reials de Nabal s'ordenà que es recuperés el control mitjançant la devolució de la quantitat total per la qual estaven arrendades (doc. 405).

20 Ibidem, docs. 384-391 (29-IX-1300). S'establiren comissions a les juntes d'Alcañiz, Aliaga, Ariza, Calataiud, Cantavieja, Castellote i aldees, Cetina i aldees, Daroca i aldees, Egea, Jaca, Montalbán, Mont-roig, Ribagorça, Tarazona i Terol i aldees, i a les sobrejuntes d'Osca i Barbastre. 
tenien una composició mixta de cavallers -generalment de dos a quatre- i homes de vila -dos o tres-, suposem que triats pels estaments corresponents. A més a més, per tal d'assegurar la contribució de tothom, s'ordenà als collectors que posaren custodes et guardias en les seues demarcacions i als oficials del rei que ajudaren els collectors in numerando personas quas in quolibet loco habent in domibus singulis numerandi ${ }^{21}$. Finalment, el Justícia d'Aragó estava facultat expressament pel monarca per a resoldre qualsevol tipus de dubte o problema que sorgís sobre el subsidi, bo i quedant obligats els col-lectors a complir les seues indicacions ${ }^{22}$.

Sense solució de continuitat, en acabar les Corts aragoneses a finals de setembre de 1300, Jaume II realitzà una tercera campanya a terres murcianes l'hivern de 1300-1301, destinada a sotmetre els castells de Lorca, Mula i Alcalá, que encara resistien o s'havien revoltat ${ }^{23}$. En març de 1301 tornà cap al regne de València, on, segons sabem a través d'una ordre de pròrroga dirigida als prohoms de la capital, havia convocat Corts per al 23 d'abril ${ }^{24}$. Tanmateix, aquell mateix mes reaparegué la Unió aragonesa, atiada pels escassos resultats del subsidi de la sal, en contrast amb els enormes deutes comptabilitzats a un memoriale de debitis que dominus rex debet in Aragone: més de 3.400.000 s.j., entre els quals destacaven els vora 120.000 s.j. deguts a l'infant Pere de Ribagorça, els 100.000 s.j. a Martín Ruiz de Foces, a Juan Ximénez de Urrea i a Pedro de Ayerbe, o els entorn de 80.000 s.j. a Gombau d'Entença i a Lope Ferrenc de Luna ${ }^{25}$. Així les coses, el rei ajornà sine die les Corts valencianes i partí cap al nord amb l'objectiu d'acabar amb la revolta, no sense abans celebrar ràpidament, entre juny i juliol, unes Corts catalanes a Lleida, com havia promès l'any anterior ${ }^{26}$.

A continuació, entre agost i octubre de 1301, Jaume II celebrà Corts amb els estaments aragonesos, aprofitant per desplegar el conegut procés judicial contra la Unió i tallar de soca-rel la resistència dels nobles ${ }^{27}$. Alguns dels

21 Ibidem, docs. 393-427 (29-IX-1300 a 12-X-1300, les cites a: doc. 404 i 393 respectivament).

22 Ibidem, doc. 392 (29-IX-1300).

23 J. D. GARRIDO, La conquesta del sud valencià i Múrcia per Jaume II, Barcelona, 2002, p 56-59.

24 ACA, C, reg. 332, f. 176v (22-IV-1301).

25 A. Canellas, «Fuentes de Zurita: Documentos de la alacena del cronista, relativos a los años 1302-1478», Cuadernos de Historia Jerónimo Zurita, 23-24 (1970-1971), p. 267-322.

26 Una constitució de les Corts de 1299-1300 fixava l'anualitat de les celebracions, alternant com a seu Barcelona i Lleida. No obstant això, les mateixes Corts de 1301 la modificaren per una altra que establia la reunió obligatòria només cada tres anys.

27 P. DE BOFarulL, «Procesos contra los nobles de la Unión Aragonesa en 1301», Colección de documentos inéditos del Archivo de la Corona de Aragón, tom XXXVIII, Barcelona, 1870. 
principals instigadors eren precisament els que tenien majors quantitats pendents de cobrament, com ara Lope Ferrenc de Luna, que era procurador del regne, Juan Ximénez de Urrea o Martín Ruiz de Foces. Tots ells, juntament amb d'altres, com Sancho de Antillón, Artal de Huerta, Lope Ximénez de Urrea, Guillén de Pueyo, Ximén Pérez de Pina o Pedro Férriz de Peña foren desterrats temporalment d'Aragó, passant majoritàriament a servir al rei de Castella, Ferran IV ${ }^{28}$. De fet, la Crònica d'aquest darrer monarca especifica una de les causes de l'alçament:

Esto fisieron los de Aragón porque los demandava el rey un pecho que desían la selga, de que se tenían por desaforados; e esta selga era desta guisa: que todas las personas que en su señorío oviese que tomasen sal, que diese cada uno dos sueldos de xaqueses [en el total dels dos anys], e desto non se escusase ninguno por fijodalgo que fuese, nin por previllejo que toviese $e^{29}$.

Per la seua banda, Zurita -que és qui detalla el nom dels desterrats- atribueix la revolta a la insuficiència de l'impost de la sal per tal de cobrir els deutes reials amb els aragonesos:

Esto fue porque los dineros de la ayuda de la sal, que el reino había otorgado al rey para pagar sus deudas, no bastaban con gran parte y era muy pequeña porción en respeto de lo que sumaban estas deudas ${ }^{30}$.

Així doncs, podem deduir que Jaume II tractà de sanejar els seus deutes amb els cavallers aragonesos tot fent contribuir als vassalls d'aquests i, fins i tot, a ells mateixos. No res menys, la col-lecta del donatiu fou magra, el que tot plegat ocasionà el rebrot de la Unió, ràpidament frenada pel rei mitjançant les Corts de 1301. En bona lògica, a més a més, l'impost de la sal fou substituit en aquella mateixa assemblea, al-legant el seu resultat valde diminutum; segons s'hi explicava, les causes del baix rendiment havien estat les enormes despeses d'administració, els nombrosos fraus i una gestió ineficaç $^{31}$. D'aquesta manera, en la segona anualitat s'abandonà tota obligació de comprar sal, substituint-la pel pagament directe de 10 d.j. per cada persona

28 Llevant de Sancho de Antillón, que no apareix al memorial esmentat, les quantitats degudes per Jaume II als altres huit castigats eren molt altes, fins a 440.000 s.j., és a dir, vora el 13\% del total dels deutes reials al regne d'Aragó: A. CANELLAS, «Fuentes de Zurita: Documentos de la alacena del cronista, relativos a los años 1302-1478», cit., p. 267-322.

29 A. BEnAVIDES, Memorias de D. Fernando IV de Castilla, Madrid, 1860, tom I, p. 90.

30 J. ZuRiTA, Anales de la Corona de Aragón, Saragossa, 1970, vol. 2, Llibre V, cap. 61.

31 L. GONZÁlez ANTÓN, Las uniones aragonesas y las Cortes del reino, cit., vol. 2, doc. 491 (3-X-1301). En novembre de 1300 ja hi havia notícies de fraus en l'administració dels col-lectors del subsidi: Ibidem, doc. 437 (14-XI-1300). 
major de 7 anys $^{32}$. I aquest tipus de subsidi -per caps- seria molt semblant al que tot seguit aprovarien les Corts valencianes.

Fet i fet, a penes un mes després de cloure l'assemblea aragonesa, de Terol estant el 18 de novembre, Jaume II convocà els estaments del regne de València a Corts per al dia de Sant Andreu, 30 de novembre de $1301^{33}$. Amb tot, l'assemblea degué començar un poc després, probablement el 4 de desembre, puix el jorn anterior el rei, ja en València, escrigué a Jaime de Xèrica demanant-li per la seua absència i informant-lo que l'esperava l'endemà pro celebracione dicte Curie generali apud dictam civitatem Valencie ${ }^{34}$. Per tant, segurament les reunions se celebraren entre el 4 de desembre de 1301 i el 21 de gener de 1302, data de clausura de l'assemblea segons constaten els privilegis que s'hi aprovaren. D'una altra banda, aquests mateixos textos indiquen que la darrera sessió se celebrà a la catedral de València, tot i que per altres fonts sabem que les reunions ordinàries tingueren lloc al convent de predicadors de la ciutat ${ }^{35}$. En conseqüència, contràriament al que ha afirmat fins ara la historiografia, que únicament ha atès als textos jurídics publicats, en avant s'haurà de tenir en compte la datació i localització que estableixen les fonts arxivístiques, és a dir, que aquelles Corts se celebraren en 1301-1302 al convent de dominics i no exclusivament en 1302 a la catedral ${ }^{36}$.

32 Ibidem, doc. 491 (3-X-1301).

33 ACA, C, reg. 332, f. 269r-270r (18-XI-1301). Van ser convocats 27 nobles, $20 \mathrm{amb}$ vincles familiars o jurídics aragonesos i 7 d'origen exclusivament català o sicilià. Eren d'origen aragonès: els tres membres de la família reial, Jaime de Xèrica, Jaime Pérez i Pedro Fernández, així com Gonzalo Ximénez d’Arenós, Pedro Ximén de Montornès, Gil Martín d'Entença, Pedro de Monteagudo, Ximén Pérez de Arenós, Fernando de Oblitas com a marmessor d'Artal de Luna, Gombau d'Entença, Pedro Ximén de Urrea, Gil Ruiz de Lihori, Sancho Pérez de Lenda, Pedro Ximén de Borriol, Pedro Ruiz de Corella, Ruy Sánchez de Calataiud, Romeo Martínez, Iñigo López de Heredia, Ximén Zapata i també Guillem d'Anglesola, nét de Blasco de Alagón. Els 7 d'origen català o sicilià eren: Ramon de Montcada, Francesc Carròs, Bernat de Sarrià, Ramon de Calvera, Hugó de Bellpuig, Francesc de Pròixita i Roger de Lloria. Pel que fa a l'estament reial, s'envià la carta de convocatòria als jurats i prohoms de 19 consells municipals: València, Xàtiva, Morvedre, Castelló de la Plana, Alpont, Castellfabib, Biar, Ademús, Castalla, Montesa, Morella, Pego, Cullera, Llíria, Borriana, Dénia, Alzira, Corbera i Gandia. Finalment, de l'estament eclesiàstic foren citats 8 membres: Berenguer de Cardona, mestre del Temple en Aragó i Catalunya, Ramon de Ribelles, castellà d'Amposta i mestre de l'Hospital de Sant Joan de Jerusalem, els bisbes de València i Tortosa, el capítol de l'església de València, un electe per l'església de Sogorb, i els abats del monestirs de Benifassà i de la Valldigna, el qual havia estat recentment fundat per Jaume II en 1298.

34 ACA, C, reg. 332, f. 270r (3-XII-1301).

35 Així ho assenyala una missiva del monarca tramesa un parell de dies abans de la clausura: ACA, C, Cartes reials, núm. 1642 (19-I-1302).

36 Els tractadistes antics, des de Llorenç Mateu fins a Vicent Boix, dataren aquelles Corts en 1301 per no tenir en compte el còmput de l'Encarnació, ja que els privilegis 


\section{EL DONATIU DE LES CORTS VALENCIANES DE 1301-1302: EL CA- BEÇATGE}

El servei aprovat per les Corts valencianes de 1301-1302 compartí uns trets i uns objectius comuns als immediatament anteriors de les Corts catalanes de 1299-1300 i les aragoneses de 1300 i 1301. En primer lloc, de nou l'Església quedà al marge del donatiu ${ }^{37}$, que fou concedit en exclusiva pels estaments nobiliari i reial. Alhora, els diners recaptats també es destinaren únicament al pagament dels deutes que el monarca tenia al propi territori, és a dir, al regne de València. Així mateix, el tipus d'impost establert, a semblança de la segona anualitat del donatiu aragonès, consistí en el pagament d'un impost directe unipersonal, tot i que en aquest cas fou anomenat «cabeçatge» i quedà fixat en 12 diners valencians -en compte de $10 \mathrm{~d}$.j.

Així ho palesen les fonts disponibles, entre les quals destaca, novament, un registre de la cancelleria reial amb ordres relatives al donatiu, al qual ens referirem com a «registre del cabeçatge ${ }^{38}$. De més a més, també comptem

aprovats estan datats a la catedral de València, el dotzè dia abans de les calendes de febrer de 1301. Modernament, Josep Martínez Aloy atorgà ja la data correcta, però fixà la celebració de les Corts en eixe únic dia - «celebróse la solemne asamblea el domingo 21 de enero del año 1302 en la iglesia mayor o Catedral de la ciudad de Valencia»-, una opinió que ha estat repetida pels historiadors posteriors. Sylvia Romeu les esmentà com a Corts de 1301-1302, però ho féu per tal de recollir aquella tradicional equivocació, aclarint que: «celebráronse el 21 de enero de 1302». Autors més recents, com María Rosa Muñoz Pomer o Pedro López Elum, les han continuat fixant exclusivament en 1302, segons reflecteix la llista de «dates i llocs de celebració de les Corts forals valencianes» que elaboraren conjuntament. Vegeu: J. MARTíNEZ Aloy, La Diputación de la Generalidad del reino de Valencia, cit., p. 79; P. LóPEZ Elum i R.M. MuÑOz POMER, «Dates i llocs de celebració de les Corts forals valencianes», a R. Pinilla (ed.), Les Corts Forals Valencianes: poder i representació, València, 1994, p. 210-211; S. RomeU, «Catálogo de las Cortes valencianas hasta 1410», cit., p. 591; P. LÓPEZ Elum, Los orígenes de los Furs en Valencia y las Cortes en el siglo XIII, cit. p. 90.

37 Aquest fet és explicitat en la resolució d'un conflicte entre els homes de l'estament reial i el monestir aragonès de Sijena pel cabeçatge de Villores, aldea de Morella, segons la qual l'ordenació del servei establia quod homines locorum religiosorum et ecclesiarum non tenerentur nobis nec alicuum solvere seu dare: ACA, C, reg. 147, f. 11v-12r (12-VIII-1310). En el cas de Beniparrell, lloc del terme de València en mans de la cartoixa de Portaceli, el procediment fou diferent, ja que la quantitat del subsidi fou inicialment pagada, però després fou traspassada al monestir descomptant-la de la recaptació reial: ACA, C, reg. 267, f. 64v-65r (11-VII-1307); V. BAYDAL, La senyoria de Beniparrell: Dels Escrivà als Escrivà de Romaní (1258-1426), Beniparrell, 2008, p. 33-34.

38 ACA, C, reg. 325, f. 70r-95v (29-XII-1301 a 21-VIII-1307). Es tracta de la segona part del registre relatiu al servei de les Corts aragoneses de 1300 i 1301, intitulat: Registrum super negocio salis olim ordinati in Aragonia pro subsidio regio. Et super auxilio regio similiter ordinato in regno Valencie. 
amb la carta d'indemnitat generada per la concessió del donatiu ${ }^{39}$, en aquesta ocasió adreçada únicament als nuclis de reialenc, ja que en el cas valencià el servei fou aprovat de manera independent pels estaments militar i reial, tot palesant la forta confrontació entre ambdós, que s'arrossegava des de les darreres dècades del segle XIII pel conflicte sobre la validesa dels furs aragonesos al regne de València ${ }^{40}$. Així doncs, dissemblantment a Catalunya i Aragó, on les comissions de diputats foren mixtes i tingueren competències tant sobre els dominis nobiliaris com sobre els reials per recaptar cises als mercats catalans i controlar la venda de la sal aragonesa -o, posteriorment, cobrar el pagament directe d'una quantitat a cada aragonès-, el donatiu de les Corts valencianes va ser ordenat per separat i gestionat per dues comissions distintes, segons explicarem a continuació.

\subsection{El cabeçatge de l'estament nobiliari (1302-1303)}

El subsidi concedit pel nobles del regne de València en les Corts de 13011302 no era conegut fins el moment a causa de l'escassa documentació disponible. De fet, contràriament al que passa amb el subsidi cobrat al reialenc, cap document explicita la forma impositiva aplicada als dominis nobiliaris per recaptar-lo, tot i que per les referències constants al cobrament d'un «cabeçatge» i el maneig de quantitats sempre exactes en sous -sense fraccionaments en diners- podem deduir que, d'igual manera, es tractà del pagament de $12 \mathrm{~d}$. (1 s.) per cada persona resident a terres nobiliàries, encara que desconeixem si en aquest cas, com en l'aragonès, també els mateixos cavallers estaven obligats a contribuir-hi.

Pel que fa a la durada, sabem que l'auxili només va ser recaptat durant l'any immediat a la seua aprovació, de 1302 a 1303, com palesen les ordres del «registre del cabeçatge» dirigides als diputats encarregats de gestionar la col-lecta nobiliària, que arriben fins a maig de 1303. No obstant això, desconeixem si el subsidi aprovat inicialment tenia una durada més llarga, ja que el del reialenc també va ser interromput per aquelles dates, tot i haver estat promès per a quatre anys, extensibles a cinc-de manera que més tard es reprengué fins a completar aquell termini. Per tant, ignorem si el servei

39 ACA, C, reg. 199, f. 44r (24-I-1302). A banda d'aquestes dues fonts bàsiques esmentades, hem consultat les cartes reials i els registres de Cancelleria 200, 268, 294, 306 i 333, compresos entre finals de 1301 i 1304, així com els llibres d'albarans i de notaments comuns del mestre racional disponibles per a aquestes dates, és a dir, els números 622, 623, 624, d'una banda, i el 774, de l'altra.

40 S. ROMEU, «Los Fueros de Valencia y los Fueros de Aragón: jurisdicción alfonsina», cit., . 75-115. 
nobiliari va ser igualment concedit per diverses anualitats, però fou cancel-lat en finir el primer any, en aquest cas de forma definitiva, puix, com s'explicità en la represa del cabeçatge del reialenc, en aquesta darrera no foren enteses los locs dels cavallers ${ }^{41}$.

D'una altra banda, sabem que per tal de gestionar la col-lecta es constituí una comissió formada per dos diputats, Pedro de Monteagudo, noble d'origen aragonès ${ }^{42}$, i Berenguer Llançol, de llinatge català, als quals anaren dirigides totes les disposicions reials referides al subsidi nobiliari ${ }^{43}$. Únicament una ordre no s'adreçà a ells, sinó al procurador del regne de València, Guillem d'Anglesola, amb l'objectiu de comunicar-li, a finals de març de 1303, que els dos diputats havien comissionat Ramon de Navàs per a acabar de collir l'auxili ordenat en les Corts de tempore preterito ab hominibus nobilium et militum dicti regni ${ }^{44}$.

Els diners de la recaptació havien de ser destinats en exclusiva al pagament dels deutes del rei amb l'estament militar del regne. Per això, de manera similar al que s'havia ordenat a l'Aragó, les ordenacions aprovades en les Corts valencianes establien que, només deu dies després de la seua clausura, el mestre racional i un escrivà reial reconeixerien els deutes de Jaume II amb els nobles i cavallers del regne, bo i expedint els corresponents albarans que permetrien assignar els diners recaptats a la liquidació dels pagaments pendents. Així, els senyors podrien retenir directament les quantitats del cabeçatge que havien de pagar els vassalls dels seus dominis, sempre i quan aquesta retenció fos verificada i comptabilitzada pels diputats nobiliaris, els quals havien de certificar-la al dors dels albarans debitoris i informar-ne al mestre racional $^{45}$.

41 ACA, C, reg. 325, f. 87rv (14-II-1304).

42 Apareix sovint en la documentació com a Pere de Montagut, senyor de Carlet, però el seu origen era indiscutiblement aragonès, de Monteagudo, com confirma el fet que aparega en les convocatòries reials de les hosts aragoneses. Cf: L. GONZÁLEZ ANTÓN, Las uniones aragonesas y las Cortes del reino, cit., «Indice onomástico»; J.R. HINOJOSA, Diccionario de historia medieval del Reino de Valencia, València, 2002.

43 Ambdós eren nobles propers a la monarquia. En finalitzar la recaptació del donatiu en 1303, Pedro de Monteagudo va ser nomenat procurador del regne de Múrcia, mentre que Berenguer Llançol fou lloctinent del procurador del regne de València uns anys després, en 1309: J.D. GARRIDO, La conquesta del sud valencià, cit., p. 60-62; J.V. CABEZUELO, Poder público y administración territorial en el reino de Valencia, 1239-1348: el oficio de la procuración, València, 1998, doc. 59 (20-V-1309).

44 ACA, C, reg. 325, f. 85v (27-III-1303).

45 ACA, C, Cartes reials, Jaume II, núm. 1791 (23-VII-1302). Les cauteles eren totalment necessàries com demostra el fet que encara en 1338 un llibre de notaments del mestre racional conservés la memòria dels 71 s. que Fernando Garcés de los Fayos havia retingut del cabeçatge dels lochs seus del regne de València, dels quals no havia volgut 
Tanmateix, a finals de maig de 1302, quatre mesos després de la finalització de les Corts, encara no s'havia realitzat l'estat de comptes pertinent, bo i provocant el malestar dels nobles. Així ho indica la resposta del mateix procurador del regne de València a l'ordre reial de preparar la defensa del territori davant les notícies d'un possible atac de tropes castellanes per la qüestió de Múrcia: la seua capacitat de maniobra era mínima per la manca total de recursos, ja que no havia rebut cap quantitat de la batllia general del regne, i al-legava que ni tan sols podria eixir de la ciutat de València perquè els cavallers no el seguirien si no.ls fahia lurs obs. Per tant, pregava al monarca que: vós me dejats acórrer almenys de la quitació a mi deguda del cabeçatge del regne o de qualsevol altre dret, per tal que pogués complir el seu deure ${ }^{46}$.

Així doncs, tot i que molts nobles ja havien estat facultats a retenir el cabeçatge dels seus llocs ${ }^{47}$, la col-lecta restava bloquejada perquè els diputats nobiliaris no podien realitzar les cauteles corresponents, segons explicava a les alçades de juliol una carta enviada a Jaume II pel bisbe de València, Ramon Despont ${ }^{48}$. Segons detallava, els comissionats Pedro de Monteagudo i Berenguer Llançol havien informat al bisbe que el mestre racional, Arnau Sabastida, i el notari reial, Bertran Desvall, contravenint les ordenacions del servei, es negaven a revisar els comptes del rei amb els nobles i a expedir els albarans de deute que permetrien assignar els diners del subsidi a la seua liquidació. En conseqüència, els nobles no estaven permetent als diputats recaptar o certificar la col-lecta del cabeçatge en els seus llocs sinó que el retenien, sense que aquells poguessen saber quant es quedava cadascú en funció d'allò que li era degut o quant estava retenint de més pel seu compte. I, a instàncies del bisbe, el mestre racional havia reconegut que aquella actuació responia als manaments del monarca, qui li havia ordenat que no realitzés cap albarà fins que no elaborés un llibre amb tots els deutes pendents i li'l mostrés per tal de decidir com actuar.

fer àpocha i, per tant, es considerava que encara els devia al rei: ACA, RP, MR, Llibres de notaments comuns, 774, f. 27r.

46 J.V. Cabezuelo, Poder público y administración territorial en el reino de Valencia, cit., p. 111 i doc. 45 (27-VII-1302).

47 Fins a maig de 1302 foren autoritzats a retenir les quantitats del cabeçatge pagades als seus llocs del regne Guillemó de Bellvís, Guillemó d'Anglesola -dels llocs del seu pare-, Pere de Morella, Bernat de Calvera, Ramon de Vilanova, Arnau de Mataró, Jaspert de Castellnou, Roger de Lloria, Tomàs de Pròixida, Ferran d'Aragó, Bernat Guillem d'Entença, Gonzalo López, Amor Dionís i Muḥammad ben Hudayr, rais de Crevillent: ACA, C, reg. 199, f. 2lr (22-I-1302); reg. 325, f. 73 r, 77v, 8lv, 83v-84r, 85r-86v (22-I-1302 a 16-V-1302).

48 ACA, C, Cartes reials, Jaume II, núm. 1792 (27-VII-1302). 
Amb tot, davant el risc de pèrdua total del subsidi, ja que els nobles estaven retenint el cabeçatge sense cap mena de control ni certificació, el bisbe prescriví al mestre racional que fes immediatament els albarans que estaven clars -amb carta del rei, albarà del batlle general valencià o dels escrivans de ració dels regnes de València i Múrcia- fins a rebre noves ordres reials. Així, finalment, sembla que es procedí a comptabilitzar els deutes del monarca amb els membres de l'estament militar, ja que pel setembre de 1302 Jaume II ordenà als comissionats nobiliaris que pagassen el salari del notari Bertran Desvall per la feina realitzada en l'escrivania del subsidi ${ }^{49}$. De fet, la recaptació efectiva durant aquella anualitat és totalment confirmada per les esporàdiques però continuades ordres reials sobre la qüestió contingudes al «registre del cabeçatge» fins a la primavera de 1303, així com per diversos albarans debitoris presentats per cavallers al mestre racional en els quals hi apareixen certes quantitats abatudes per la retenció del cabeçatge dels vostres locs que són en lo regne de València ${ }^{50}$.

Altrament, en cas que un senyor no tingués cobraments pendents del rei o que amb la suma recaptada als seus dominis hi hagués suficient per pagar la suma que li era deguda, les quantitats sobrants passaven a ser gestionades pels diputats nobiliaris, els quals podien destinar-les a liquidar altres deutes pendents del monarca amb els nobles, tot i que desconeixem el seu grau d'autonomia a l'hora de disposar d'aquells diners ${ }^{51}$. En aquest sentit, únicament sabem que amb posterioritat el mestre racional acabà rebent els llibres dels collidors del cabeçatge ${ }^{52}$, el que sembla

49 ACA, C, reg. 325, f. 75r (IX-1302).

50 És el cas dels albarans presentats per Francesc Carròs, Juan Ximénez de Oris, Ximén Pérez d'Arenós, Gil Martín d'Entença o Ximén Zapata, amb quantitats abatudes del cabessatge del primer any sempre en xifres exactes en sous (1.552 s., 1.078 s., 808 s., 66 s. o 838 s.): ACA, RP, MR, Llibres d'albarans, 622, f. 55v, 71r, 74v, 78r, 106r. En el cas concret de Guillem d'Anglesola el mestre racional anul-là l'abatiment de $1.882 \mathrm{~s}$. anotat en un dels seus albarans en concepte de cabeçatge, ja que no el collí ni reebés ne feés cullir ne reebre: Ibidem, f. 67r.

51 D'un cantó, los collidors dels locs dels cavallers del regne de València realitzaren, sense manament reial documentat al «registre del cabeçatge», dos pagaments a Martín Ximén Romeo i el mateix diputat Pedro de Monteagudo: ACA, RP, MR, Llibres d'albarans, 622, f. 15r (10-II-1307) i 97r (26-III-1308). D'un altre cantó, coneixem dos ordres específiques del rei per tal que els diputats nobiliaris pagassen, de peccunia dicti auxilii, unes quantitats degudes a Gueralda, vídua de Berenguer de Vilaragut, i a Guillemó de Bellvís, en aquest darrer cas si els diners del cabeçatge dels seus llocs no bastaven per a liquidar els cobraments pendents: ACA, C, reg. 325, f. 75v (20-II-1302); reg. 199, f. $2 \operatorname{lr}(22-\mathrm{I}-1302)$.

52 Així s'explicitava, fent referència al libre terç dels collidors, en el notament sobre la retenció del cabeçatge dels llocs de Fernando Garcés de los Fayos del qual hem parlat anteriorment: deu al senyor rey, los quals se retench del cabeçatge dels lochs seus del regne 
indicar una supervisió comptable per part de la monarquia. Tanmateix, no podem comprovar si els diputats hagueren de retre els comptes de la recaptació davant el mestre racional tot rebent-ne un albarà certificatori, ja que no s'han conservat els llibres d'albarans de 1303 a 1306, de manera que, amb la informació de la qual disposem, resulta impossible concretar la naturalesa de la seua relació.

En tot cas, pel que fa a la resta d'aspectes que hem vist, podem concloure que el subsidi de l'estament militar aprovat com a servei en les Corts valencianes de 1301-1302 va consistir en el pagament d'l s. per cada persona habitant en els dominis nobiliaris, que va ser recaptat durant un any per una comissió de dos diputats cavallers, que, si més no, estigué sotmesa a un cert control per part de l'administració reial.

\subsection{El cabeçatge de l'estament reial (1302-1308)}

El donatiu aprovat per l'estament reial en les Corts valencianes de 13011302 ja era conegut per la historiografia, però de forma molt esbiaixada, únicament a través del privilegi que reordenà la seua represa el 14 de febrer de $1304^{53}$. A partir del contingut d'aquest document, Josep Martínez Aloy interpretà que en les Corts de 1302 els nuclis reials haurien ofert $560.000 \mathrm{~s}$. al monarca en quatre anys a raó de 140.000 s. anuals, però la recaptació del primer any hauria fracassat, no arribant a penes als $100.000 \mathrm{~s}$. Segons aquest autor, d'una altra banda, la forma de contribució hauria estat des de l'inici un impost repartit proporcionalment en base al patrimoni dels veïns, com en les talles o quèsties habituals. Per això, els dirigents urbans haurien decidit taxar en molt als exempts amb l'objectiu de fer minvar la xifra que havia de pagar la resta, motivant així el fracàs de la col-lecta. En conseqüència, Jaume II hauria suspès els privilegis concedits en les Corts fins que en febrer de 1304 els síndics de les universitats renegociaren l'ajuda i acordaren elevar la quantitat a $150.000 \mathrm{~s}$. anuals durant quatre anys més, tot completant un total de cinc anualitats que incrementaven la suma total fins als $700.000 \mathrm{~s}$. $(100.000 \mathrm{~s} \text {. del primer any fallit i } 150.000 \mathrm{~s} \text {. dels quatre anys posteriors })^{54}$. En consonància amb això, els historiadors que han tractat la qüestió després no han aportat cap variació rellevant d'aquesta versió, malgrat que ni el tipus

de València, de què no volch fer àpocha segons que.s contén e.l libre terç dels collidors en cartes CXL - LXXI sous reials; ACA, RP, MR, Llibres de notaments comuns, 774, f. 27r.

53 L. Alanyà (ed.), Aureum Opus regalium privilegiorum civitatis et regni Valencie, València, 1999, «Iacobi secundi», XI (14-II-1304). Hem transcrit, més avall, la còpia d'aquest document continguda al «registre del cabeçatge»: «Apèndix documental», doc. 2.

54 J. Martínez Aloy, La Diputación de la Generalidad del reino de Valencia, cit., p. 78-82. 
d'impost aplicat ni la durada inicial del subsidi establerts per Martínez Aloy són correctes ${ }^{55}$.

En primer lloc, gràcies a la carta d'indemnitat atorgada per Jaume II a l'estament reial en 1302 per tal d'assegurar que el subsidi concedit no creés precedent -explicitant que es donava de gracia i liberaliter-sabem que aquell consistia en el pagament anual de $12 \mathrm{~d}$. per part de cada persona habitant en el reialenc: homes i dones, cristians, musulmans i jueus, fossen de la jurisdicció, condició o edat que fossen ${ }^{56}$. Per tant, la forma impositiva era la d'un pagament directe per caps, un «cabeçatge» com és anomenat en la major part de la documentació disponible, i no la d'una contribució en funció dels béns posseïts. Amb tot, en quedaven lliures els pauperes et impotentes, la part dels quals hauria de ser suplerta pels divites et potentes de cada vila, segons el que ordenarien els col-lectors del donatiu i els jurats de València ${ }^{57}$.

En segon lloc, el mateix document revela que l'impost havia de ser pagat anualment durant quatre anys, extensibles a cinc en cas que els diners recaptats durant aquell període no fossen suficients per tal de liquidar els deutes que el rei tenia al regne de València. Per tant, contràriament al que postulà Martínez Aloy, ja des d'un principi es contemplava una durada de cinc anualitats, les quals, com podrem veure, es pensava que podien rendir uns $140.000 \mathrm{~s}$. per any fins a obtenir una ajuda total aproximada de 700.000 s. En aquest sentit, la quinquennalitat del donatiu -prevista com a possible en la carta d'indemnitat- és plenament confirmada per una ordre enviada als oficials del rei pocs dies després de la clausura de les Corts, bo

55 S. RomeU, «Catálogo de Cortes valencianas hasta 1410», cit., p. 591; P. LóPEZ ELum, Los orígenes de los Furs en Valencia y las Cortes en el siglo XIII, cit., p. 88-89; M.R. MuÑoz POMER, «Cortes y fronteras de Valencia en el siglo de Alcañices (1250-1350)», cit., p. 755,763 i 771.

56 ACA, C, reg. 199, f. 44r (24-I-1302), transcrit a l'«Apèndix documental», doc. 1. Aquesta carta, expedida a penes tres dies després de la clausura de les Corts, havia restat inèdita fins ara. És el correlat de les cartes d'indemnitat fetes per la venda del bovatge català i el subsidi de la sal aragonès, tot i que, com hem explicat, no incloïa l'estament nobiliari sinó que es dirigia exclusivament al reial. En aquest sentit, pensem que el fet que s'adrecés a tots els iuratis, probis hominibus et universitati civitatis Valencie necnon universis singulis hominibus villarum et aliorum locorum in regno Valencie constitutorum et universis hominibus in dicto regno habitantibus, s'ha d'entendre segons la usual confusió de l'estament reial amb la integritat del regne, present en la majoria de documents reials valencians d'aquesta època.

57 ARV, Alpont, pergamins, núm. 8 (29-I-1302). Desconeixem la forma exacta de distribució de la part que pertocava als pobres entre la resta de veïns de cada vila, ja que el document que informa d'aquest fet simplement indica que els jurats i prohoms del lloc corresponent haurien de complir allò ordenat pels diputats col-lectors i pels jurats de València super relevacione dictorum pauperum. 
i informant-los que el braç reial havia aprovat una ajuda per quinque annos sequentes $^{58}$.

Ultra això, a través de les informacions proporcionades pel «registre del cabeçatge», sabem que per tal de gestionar el subsidi les universitats reials havien de triar anualment una comissió de quatre diputats col-lectors, dos escollits per la ciutat de València i els altres dos alternativament cada any per Morella i Xàtiva o per Morvedre i Alzira ${ }^{59}$. D'aquesta manera, els dos comissionats de València s'encarregarien de la capital i el seu terme, i un ajudaria al de Morella o Morvedre en la lloctinència citra Xucarum mentre que l'altre faria el mateix amb el de Xàtiva o Alzira en la lloctinència ultra Xucarum, comptant tots ells amb l'assistència dels jurats de la capital a l'hora de realitzar les estimacions per tal de suplir la part corresponent als pobres de cada $1 l o c^{60}$.

D'altra banda, durant el període de pagament del cabeçatge un privilegi reial garantia als nuclis reials, atenentz al servii et ajuda concedits, l'exempció de tota quèstia e quèsties, e d'ost e de cavalgada e de reemció d'aquelles, per aytans ans com la dita ajuda durés ${ }^{61}$. Tanmateix, aquesta franquesa, així com també la resta de privilegis i gràcies atorgats en el context de les Corts, quedaren anul.lats al llarg de 1303, ja que, com efectivament va interpretar Martínez Aloy, el subsidi rendí el primer any una quantitat molt menor a l'esperada i fou cancel-lat. En conseqüència, en setembre de 1303 el monarca, en substitució de la segona anualitat del cabeçatge, exigí una quèstia ordinària, és a dir, la petició d'una suma determinada a cada vila i obtinguda mitjançant un impost de repartició en base a la fortuna patrimonial de cada foc, com s'havia fet usualment al llarg del segle XIII ${ }^{62}$. Amb tot, a començaments de

58 S'hi explicitava que havia estat atorgada in subsidium debitorum que debemus exsolvendorum prout stitit ordinatum fuisse et in scriptis redactum ac etiam publicatum secundum capitula de predictis ordinata. Aquest document va ser publicat a partir d'un trasllat notarial conservat en un arxiu privat: J.M. DEL ESTAL, Alicante. De villa a ciudad (1252-1490), Alacant, 1990, doc. 75 (29-I-1302).

59 Eren elegits ad scribendum, levandum et conservandum peccuniam auxilii predicti, havien de jurar el seu càrrec davant el rei o el batlle general del regne i tenien dret a percebre un salari, la quantitat del qual desconeixem: ACA, C, reg. 325, f. 83r (13-XII-1302).

60 ACA, C, reg. 325, f. 90v-91r (24-X-1304) i 95v (VIII-1307).

61 ACA, C, reg. 199, f. 18v (21-I-1302).

62 Sobre el tribut de la quèstia, vegeu, entre d'altres: A.J. Mira i P. Viciano, «La construcció d'un sistema fiscal: municipis i impost al País Valencià (segles XIII-XIV)», Revista d'Història Medieval, 7 (1996), p. 135-148; J. TORRÓ, «Colonització feudal i renda feudal. L'origen de la peita al regne de València», a M. Sánchez Martínez, A. Furió i P. Bertran (eds.), Actes: Col-loqui Corona, municipis i fiscalitat a la Baixa Edat Mitjana, Lleida, 1997, p. 467-491; A. FURIÓ, «L'impôt direct dans les villes du rouyame de Valence», a D. Menjot i M. Sánchez Martínez (eds.), La fiscalité des villes au Moyen 
1304 el subsidi aprovat en Corts fou reprès sota noves condicions durant quatre anualitats més, bo i completant les cinc previstes en inici, un fet que comportà la restitució dels privilegis reials que havien estat concedits.

- La primera anualitat del cabeçatge reial (1302-1303)

Segons acabem d'explicar, el subsidi ofert per l'estament reial com a donatiu de Corts es va regir durant la seua primera anualitat, entre 1302 i 1303, per les ordenacions que hi foren aprovades, segons les quals totes les persones residents al reialenc havien de pagar un cabeçatge d'l s., amb el que es pensaven recaptar entorn de $140.000 \mathrm{~s} .{ }^{63} \mathrm{I}$ per a gestionar la col-lecta es nomenà una comissió de quatre diputats, conformada per Bernat Desclapers i Tomàs Fabre, escollits per la ciutat de València, Guillem Destorms per Morella i Berenguer de Fluvià per Xàtiva. D'ells sabem, per exemple, que: Desclapers era un ric ciutadà de la capital, batlle de la reina, freqüent conseller del municipi, jurat de València durant el jurament reial de Jaume II en 1292, fermança del rei en nombrosos préstecs, comprador de rendes i possessions a diverses parts del regne, i posteriorment fundador de l'hospital d'en Clapers; Fabre també estigué present en la jura de Jaume II i fou jurat de València en l'anualitat de 1306-1307, així com conseller municipal i prestador del rei en els anys subsegüents; Destorms va ser un dels dos síndics de Morella en el jurament al rei de 1292, s'ocupà posteriorment de l'administració dels béns de diverses comandes del Temple intervingudes al nord del regne, fou batlle de Peníscola i prestà importants quantitats de blat per a la conquesta d'Almeria en 1309; finalment, Berenguer Fluvià exercí per aquests anys com a lloctinent de procurador del regne dellà Xúquer i també realitzà préstecs al monarca per a l'empresa almerienca ${ }^{64}$.

Âge (Occident méditerranéen). 4. La gestion de l’impôt, Tolosa de Llenguadoc, 2004, p. 169-199.

63 Diverses ordres reials recalcaren la universalitat del pagament davant les notícies sobre certs batlles, porters, jutges i altres persones que asseguraven tenir privilegi de franquesa-segurament aplicable a les quèsties: ACA, C, reg. 325, f. 79v (8-VII-1302) i 80r (31-VIII-1302).

64 Dades disperses extretes de: ACA, C, reg. 55, f. 56r-58r (jurament del rei en 1292); V. ANYÓ, El primer 'Manual de Consells' de la ciutat de València, València, 1997 (càrrecs de jurats i consellers de València durant aquests anys); ACA, RP, MR, Llibres d'albarans, 623, f. 81v (Desclapers, batlle de la reina); ACA, RP, MR, Llibres de notaments comuns, 774, f. 4r (Desclapers, fermancer del rei); ACA, C, reg. 196, f. 139v (llicència a Desclapers per edificar un molí a Benicalap); E. Olmos, Inventario de los pergaminos del Archivo de la Catedral de Valencia, València, 1961, docs. 877 i 1050 (compra de terres i rendes per part de Desclapers); ACA, C, Cartes reials, 2023 (Destorms, batlle de Peníscola en 1304); ACA, RP, MR, Llibres d'albarans, 624, f. 28v (Destorms, administrador de les comandes del Temple a Orta i Cantavella); ACA, RP, MR, Llibres 
Així doncs, tots els col-lectors eren prohoms destacats, que ocupaven recurrentment càrrecs de poder en els consells municipals o en l'administració reial, bo i rebent ara la facultat de gestionar aquell donatiu a la integritat del reialenc valencià. En relació amb això, per tal de recaptar el cabeçatge, sabem que els diputats realitzaren un llistat de totes les persones residents als dominis reials, segons es desprèn de la petició feta al monarca per tal de concedir-ne franquesa a les viles de Biar i Castalla -l'única que coneixem durant aquesta primera anualitat-, després que els mateixos diputats hagueren comprovat el seu estat de penúria quan hi anaren causa scribendi nomina hominum eorundem locorum ${ }^{65}$. De fet, també sabem que varen confeccionar fins a 37 libres de la cullita del cabeçatge, que no s'han conservat però que apareixen esmentats en un document del mestre racional, bo i oferint una ràpida panoràmica dels llocs on es pagà el donatiu del braç reial ${ }^{66}$.

En primer lloc, hi contribuïren 17 de les 19 universitats reials que havien estat convocades a Corts, és a dir, totes (València, Morella, Xàtiva, Morvedre, Alzira, Castelló de la Plana, Borriana, Llíria, Cullera, Corbera, Montesa, Gandia, Pego, Dénia, Ademús, Alpont i Castellfabib), excepte les enfranquides Biar i Castalla. De més a més, s'hi inclogueren les alqueries, aldees, moreries o jueries dels respectius termes municipals, si més no en el cas de València, Morella, Xàtiva, Alzira i Cullera, en què són explícitament esmentades. En segon lloc, pagaren altres nuclis reials no convocats a les Corts, però que usualment participaven en les quèsties demanades pel monarca, com ara Vila-real, Penàguila i Xixona. En tercer lloc, també estigueren sotmesos al cabeçatge els llocs de musulmans pertanyents a Jaume II, com Uixó, Alme-

de notaments comuns, 774, f. 5v (préstec de blat de Destorms); J.V. CABEZUELO, Poder público y administración territorial en el reino de Valencia, cit., doc. 48 (30-III-1303) (Fluvià, lloctinent del procurador); ACA, C, reg. 267, f. 240r; reg. 271, f. 5r-6r (IV1309) (Fluvià, Fabre i Desclapers, prestadors del rei per a la conquesta d'Almeria). Sobre l'hospital d'en Clapers, vegeu els treballs d'A. RuBIO: «Una fundación burguesa en la Valencia medieval: el hospital de En Clapers», Dynamis, 1 (1981), p. 17-49; «Un hospital medieval según su fundador: el testamento de Bernat dez Clapers (Valencia, 1311)», Dynamis, 3 (1983), p. 373-387; Pobreza, enfermedad y asistencia hospitalaria en la Valencia del siglo XIV, València, 1984.

65 Un poc després s'hi sumà a la franquesa al llogaret proper de Favarella, per les mateixes causes: ACA, C, reg. 325, f. 80r (31-VII-1302) i 81r (27-VIII-1302).

66 Els llibres van ser presentats pels diputats al mestre racional, que els deixà als comissionats del nou subsidi reprès en 1304 , però aquests no els van tornar i la seua devolució quedà registrada en un llibre de notaments comuns com a operació pendent: ACA, RP, MR, Llibres de notaments comuns, 774, f. 39rv, transcrit a l'«Apèndix documental», doc. 3. La radiografia del reialenc valencià a començaments del segle XIV oferta per aquest document coincideix, de forma general, amb la realitzada per E. GuINOT, «La creació de les senyories en una societat feudal de frontera: el regne de València (Segles XIII-XIV)», Revista d'Història Medieval, 8 (1997), p. 79-108. 
díxer, Fondeguilla, Madrona, Bolbait i Gallinera. I, finalment, hi contribuïren alguns altres llocs que estaven en possessió de senyors ciutadans, com Orpesa, de Berenguer Dalmau, i Murla, de Berenguer Mercer, o de cavallers, com Alcalà, que estava infeudada pel rei a Ponç Guillem de Vilafranca ${ }^{67}$.

No obstant això, malgrat l'ambició del procediment, el subsidi fracassà, ja que sobre els 140.000 s. previstos a penes es recaptaren 100.000 s., segons es pot deduir dels comptes i assignacions anotats al «registre del cabeçatge», que recollí les cartes enviades per Jaume II al llarg d'aquella primera anualitat super solucionibus faciendis ex auxilio ordinato noviter in Valencie. En aquest sentit, sabem que ja des de finals de gener de 1302, és a dir, uns pocs dies després de la finalització de les Corts, el rei començà a disposar assignacions a tort i a dret sobre el subsidi, fins al punt que a principis d'abril n'havia atorgat a 26 beneficiaris per valor d'uns 200.000 s. ${ }^{68}$ Tanmateix, potser per aquesta ràpida acumulació, el 7 d'abril manà als col-lectors que suspengueren tot pagament, li transmeteren en un quadern els que havien fet ja, i no realitzaren cap altre fins a nova ordre. No coneixem el resultat d'aquesta clarificació de comptes, però, posteriorment, entre abril i octubre de 1302, només es feren unes poques assignacions més, concretament set per un total d'uns 20.000 s. Finalment, el 9 de desembre de 1302 es realitzà una nova comptabilització per la qual sabem que únicament havien estat fets efectius quatre pagaments per valor de 47.659 s. 2 d. ${ }^{69}$, bo i ordenant-se ara que es pagués una nova assignació de 4.000 s., així com altres vuit anteriors que sumaven 43.000 s. $^{70}$ Així, la suma dels pagaments realitzats i dels ordenats

67 F. SeVillano, Bosquejo histórico de Oropesa del Mar, Orpesa, 1953; S. Giner, Historia de Murla, Alacant, 1995, p. 119-120; ACA, C, reg. 325, f. 94v (3-IX-1306) (Ponç Guillem de Vilafranca, senyor infeudat d'Alcalà).

68 ACA, C, reg. 325, f. 70r-77r (23-I-1302 a 9-IV-1302). Fins i tot abans de finalitzar les Corts, des de desembre de 1301, s'hi pot documentar alguna assignació sobre el futur donatiu: ACA, C, reg. 325, f. 70v (29-XII-1301) i 72v (6-I-1302); reg. 268, f. 258v-259r (9-I-1302).

69 ACA, C, reg. 325, f. 82 (9-XII-1302): Es tractava de 30.000 s. pagats al canvista de València Bernat Planell; 10.000 s. al també canvista valentí Bernat Llémena, per certs negocis del rei; 5.659 s. 2 d. a Bernat Desclapers, per la fermança amb interessos que havia fet al rei per comprar una heretat a Simat; i $2.000 \mathrm{~s}$. als falconers reials de València, per la seua quitació pendent de més de $15.000 \mathrm{~s}$.

70 Ibidem: La nova assignació, de 4.000 s., s'adjudicava a Joan Amell, físic reial. Les antigues eren: $20.000 \mathrm{~s}$. a Guillem Escrivà, reboster reial, per tal de pagar els homes del viatge a Sicília; 15.000 s. al noble Pere de Queralt dels 20.000 s. que li estaven assignats al subsidi; 3.000 s. al conseller reial Ramon de Vilanova dels 10.000 s. que li eren deguts; altres $2.000 \mathrm{~s}$. als falconers reials; $1.000 \mathrm{~s}$. dels $7.240 \mathrm{~s}$. deguts a Ginesa, vídua de Jaume Santomera, pels censos pendents de la carnisseria d'Alzira i altres deutes; $1.000 \mathrm{~s}$. a Salvador de Terol, cavaller de la casa reial; 500 s. a Guillem Desvall, també nomenat del Cano, de la familia reial; i altres 500 s. a Mateu Pujalt, de la cambra del rei. 
llavors representava un total de 94.659 s. 2 d., el que s'ajustava als 95.000 s., plus vel minus, que s'havien recaptat fins a aquell moment, segons informaven els collectors ${ }^{71}$.

El més probable, a més a més, és que aquestes darreres ordres de pagament, ja ajustades a la quantitat recaptada, s'abonaren finalment de la mà dels diputats de les universitats reials ${ }^{72}$. I podem dir que totes elles estaven efectivament destinades a liquidar deutes contrets pel rei al regne de València. Per exemple, el pagament més important fou el realitzat al campsor valentí Bernat Planell, al qual s'havien assignat els primers 60.250 s. que es recaptassen del cabeçatge, a dipositar en la seua taula fins a la festa de Sant Joan de 1302, quan havien de ser retirats per a dipositar-los en la caxia del Temple de València, on es guardava la resta del numerari reunit ${ }^{73}$. No obstant això, malgrat que el canvista tenia en penyora 18 prohoms valencians, retinguts com a hostatges prop de Silla per un deute total de $110.000 \mathrm{~s}$. que el rei mantenia amb ell, finalment només li foren pagats $30.000 \mathrm{~s}$. de la primera anualitat del cabeçatge ${ }^{74}$.

Per una altra banda, 20.000 s. assignats al reboster reial Guillem Escrivà havien de servir per pagar els homes de mar de les expedicions de Sicília, segurament els de les galeres armades a València, atès l'àmbit d'actuació preferent d'aquell personatge i la seua associació en aquest pagament a Pere de Ribalta, ciutadà de la mateixa capital valenciana ${ }^{75}$. Igualment, els 15.000 s. destinats al noble català Pere de Queralt semblen pertànyer als pagaments pendents del rei pel seu recent càrrec de procurador del regne de València, mentre que, per la seua banda, la major part dels $10.000 \mathrm{~s}$. dipositats en la taula del canvista valencià Bernat Llémena s'empraren per alleugerir un deute que el rei tenia amb el tresorer de la reina, Bernat d'Esplugues, pel qual tenia obligada la vall d'Uixó ${ }^{76}$. Finalment, també la resta d'assignacions menors corresponia a deutes amb cavallers, oficials, ciutadans o habitants del territori valencià, com ara Ramon de Vilanova, heretat al regne, Salvador de

71 Ibidem.

72 De fet, sabem a ciència certa que Guillem Escrivà rebé 18.000 s. dels 20.000 s. assignats i Guillem del Cano 450 s. dels 500 s., i, encara a finals de gener de 1303, els col-lectors manifestaren que després de fer els pagaments romanien lliures 1.600 s. 10 d., els quals el monarca ordenà transferir a Guillem Escrivà per aquells 2.000 s. que li mancaven: ACA, RP, MR, Llibres d'albarans, 622, f. 12v; C, reg. 325, f. 84rv (17-I-1303 i 28-I-1303).

73 ACA, C, reg. 325, f. 70r (23-I-1302).

74 ACA, Cartes reials, núm. 1795 (20-VIII-1302); ACA, RP, MR, Llibres d'albarans, 624, f. $98 \mathrm{v}$.

75 ACA, RP, MR, Llibres d'albarans, 622, f. 55v-56r.

76 ACA, RP, MR, Llibres d'albarans, 622, f. 162r. 
Terol, alcaid de Llíria, Mateu Pujalt, alcaid de Penàguila, Guillem del Cano, que havia estat justícia de València, Joan Amell, físic major del rei establert a València, els falconers reials del regne, el ciutadà valentí Bernat Desclapers, o Ginesa, vídua de Jaume de Santomera, que cobrava rendes de la carnisseria d'Alzira ${ }^{77}$.

Així doncs, com decretaven els capítols del subsidi, els diners del cabeçatge de la primera anualitat foren destinats en exclusiva a pagar deutes de la monarquia contrets al regne de València. D'una altra banda, sabem que aquella distribució dels aproximadament $95.000 \mathrm{~s}$. realitzada a començaments de desembre de 1302 coincidí amb els darrers moments de la recaptació, ja que a penes uns dies després el rei ordenà als consells municipals corresponents que triassen els nous diputats de l'any següent ${ }^{78}$. De fet, posteriorment només es realitzà una nova assignació pertanyent a la primera anualitat del donatiu, per valor de $2.200 \mathrm{~s}$., destinada precisament a un dels diputats d'aquell primer any, Guillem Destorms, de Morella, que en abril de 1303 fou cridat a València per retre comptes de la gestió del subsidi, tot palesant que aquest ja s'havia acabat de col.lectar ${ }^{79}$.

Amb tot, si es va produir, no coneixem cap dada del retiment de comptes dels diputats del primer any del cabeçatge reial, que potser es podria trobar en els llibres d'albarans del mestre racional de 1303 a 1306, que, com hem dit, no s'han conservat. En qualsevol cas, a partir de les dades que hem exposat, podem suposar que la suma reunida rondà els 100.000 s., en compte dels 140.000 s. que s'havien estimat en principi. En conseqüència, el subsidi fou cancel-lat en començar la segona anualitat atès que no acomplí les expectatives inicials, bé a causa d'una estimació excessiva de la població total del reialenc -encara que sembla una errada massa gran si tenim en compte que l'administració reial comptava amb les dades demogràfiques proporcionades

77 J.R. Hinojosa, Diccionario de historia medieval del Reino de Valencia, cit. (Queralt, Vilanova, Terol i Pujalt); L. CIFuentes i M.R. MCVAugh (eds.), Arnaldi de Villanova opera medica omnia, vol. X.2: Regimen Almarie (Regimen castra sequentium), Barcelona, 1998, p. 26 (Amell, del regne de València, oriünd d'Occitània); ACA, RP, MR, Llibres d'albarans, 622, f. 12v (Cano, justícia de València).

78 ACA, C, reg. 325, f. 83r (13-XII-1302). Els escollits pertanyien també als cercles del poder municipal. Per València foren triats Ramon de Poblet i Pere de Ripoll, presents en el jurament reial de Jaume II en 1292 i consellers de la ciutat, així com lloctinent enllà Xúquer el segon; per Morvedre, Joan Ferran, i, per Alzira, Bernat Batlle, de la familia del bisbe Ramon Despont i sequier major de la vila: ACA, C, reg. 55, f. 56r-58r (jurament de 1292); V. ANYÓ, El primer 'Manual de Consells' de la ciutat de València, cit. (consellers de València); J.V. CABEzUelo, Poder público y administración territorial en el reino de Valencia, cit., doc. 59 (20-IV-1309) (Ripoll, lloctinent); ACA, C, reg. 201, f. 66 (28-XII-1303) (Batlle, sequier).

79 ACA, C, reg. 325, f. 84r (20-I-1303) i 86r (7-IV-1303). 
per la col-lecta periòdica dels monedatges des de 1266-, o bé a causa d'un alt grau d'evasió fiscal. En aquest sentit, cal tenir en compte que durant aquell mateix any de 1302 també fou demanat a terres valencianes un monedatge, el que potser influí en l'escassa recaptació del cabeçatge promès en Corts i provocà la seua anul.laciós ${ }^{80}$.

\section{- La cancel-lació del cabeçatge reial i la quèstia de 1303}

Les escasses tres disposicions incloses al «registre del cabeçatge» entre gener i maig de 1303 confirmen que la seua recaptació fou suspesa a l'inici de la segona anualitat. Així, si bé en desembre de 1302 Jaume II acceptà el nomenament del diputat triat pel consell d'Alzira, a penes unes setmanes després, el 8 de gener de 1303, ordenà la interrupció temporal del donatiu i cridà els nous col-lectors a Tortosa, per tractar ex quibusdam casis racione auxilii supradicti. I, en consonància amb això, la següent ordre, de maig de 1303, assignà un nou pagament al cabeçatge, però la seua mateixa tenor palesava que la recaptació del subsidi restava en l'aire, puix el consignava també a qualsevol altra quantitat obtinguda pel rei al regne ${ }^{81}$.

Fet i fet, les ordres s'interrompen bruscament en aquell moment i no tornen a reaparèixer fins a febrer de 1304, quan el cabeçatge es reprengué durant quatre anys més. Per tant, el subsidi fou cancel-lat al llarg de la primera meitat de 1303, el que és plenament confirmat per la petició d'una quèstia reial poc després, car, una vegada suspès el servei de les Corts, també quedà anul.lada la franquesa temporal de quèsties i redempcions d'host que l'acompanyava ${ }^{82}$. Així, concretament el 27 d'agost, tres mesos després de la darrera ordre de 1303 continguda al «registre del cabeçatge», Jaume II demanà a les viles reials certes quantitats de diners invocant les despeses fetes per a l'adquisició i la defensa del regne de Múrcia ${ }^{83}$. Aquest tribut, però, era ben diferent del cabeçatge, que era unipersonal i fix, alhora que universal i obligatori per a tots. D'una banda, la quèstia consistia en el pagament d'una quantitat determinada globalment per a cada vila, que es recaptava proporcionalment als béns posseïts pels veïns, mentre que, d'una altra banda, les franqueses personals o municipals d'aquella exacció reial ja atorgades, així com les assignacions prèvies, comprometien bona part dels diners obtinguts.

80 Segons diverses anotacions d'un registre Monetatici, el morabatí fou demanat pel rei in anno Domini millesimo $C C C^{o} I^{o}$ in festo nathalis Domini, però no fou levatum et collectum pels recaptadors fins a l'anno Domini $\mathrm{M}^{o} \mathrm{CCC}^{\circ}$ secundo, in festo Sancti Michaelis: ACA, C, reg. 304, f. 153r-155r.

81 ACA, C, reg. 325, f. 83r (13-XII-1302), 83r (8-I-1303) i 86v (V-1303).

82 ACA, C, reg. 199, f. 18v (21-I-1302).

83 ACA, C, reg. 333, f. 130r-134v (27-VIII-1303). 
Per exemple, la ciutat de València n'era lliure des de 1286 i en aquesta ocasió simplement rebé una convocatòria d'host, bo i minant de forma considerable la quantia total a percebre respecte al recent donatiu de Corts, en què la seua contribució quedava garantida ${ }^{84}$. A més a més, fins a huit nuclis gaudien de franqueses provisionals, al temps que bona part del producte de les quèsties estava bloquejat per la concessió temporal de moltes de les viles a diversos membres de la casa reial (una liberalitat segurament permesa pel fet que el monarca no pensava demanar quèsties durant el mateix període que durés el cabeçatge). Així, el rei no pogué obtenir cap suma de Borriana, Castelló de la Plana, Montesa, Cullera, Dénia, Xixona, Castalla i Biar, ja que llavors estaven exemptes, ni tampoc de les principals viles del regne, Morella, Alzira, Morvedre, Llíria i Corbera, que estaven cedides a la reina Blanca amb tots els seus drets i esdeveniments, així com també les de Gandia i Pego a l'antiga emperadriu bizantina Constança ${ }^{85}$. D'aquesta manera, després de les franqueses i remissions parcials, dels 106.000 s. demanats inicialment només se'n pogueren recaptar 63.400 s., dels quals 42.000 s. havien d'anar a parar a la reina i $5.200 \mathrm{~s}$. a la princesa grega. Val a dir, que el rei únicament podia emprar d'aquella recaptació la paupèrrima suma de $16.200 \mathrm{~s}$.

Amb tot, per tal de comparar amb la quantitat col-lectada a través del donatiu reial de Corts, també hi hem de afegir les peticions que el monarca va realitzar en 1303 als musulmans i els jueus, ja que aquests quedaven igualment inclosos en el cabeçatge. Així, per una banda, sabem que Jaume II va sol-licitar un total de 16.500 s. als musulmans de València, Xàtiva, Morvedre, Alzira, Castelló de la Plana, la vall d'Uixó, Gallinera, Pego, Dosaigües i Almedíxer, dels quals només restaren $9.500 \mathrm{~s}$. una vegada fetes les remissions i l'assignació d'un violari a la mateixa princesa Constança ${ }^{86}$. Per l'altra banda, el rei demanà 25.000 s. a les aljames jueves del regne, dels quals finalment quedaren 16.000 s. $^{87}$ Així doncs, tot i que desconeixem els comptes finals de la recaptació que havien de presentar els porters davant el mestre racional -segurament inclosos en els llibres d'albarans no conservats de Bernat Rodera-, podem dir que d'aquella petició fiscal el monarca només pogué comptar directament amb un màxim de 41.700 s.: 16.200 s. dels cristians, $16.000 \mathrm{~s}$. dels jueus i $9.500 \mathrm{~s}$. dels musulmans ${ }^{88}$.

84 L. Alanyà (ed.), Aureum Opus, cit., «Alfonsi primi», I (20-IX-1286).

85 ACA, C, reg. 333, f. 130r-134v.

86 ACA, C, reg. 333, f. 132rv (29-IX-1303).

87 ACA, C, reg. 333, f. 144v (29-I-1304).

88 Als llibres de tresoreria podem observar que part de la recaptació anà a parar al tresorer reial, ja que entre novembre de 1303 i febrer de 1304 els porters Bernat de Ginebret i Arnau Cortit li lliuraren fins a 26.044 s. 8 d. d'aquesta culleta del regne 
Aquesta, segurament, fou la principal raó per la qual Jaume II estigué interessat a reprendre el donatiu de Corts anul.lat, en tant que sobre aquell no hi havia assignacions anticipades ni franqueses perpètues o temporals. Al mateix temps, els prohoms urbans també devien estar interessats a recuperar els privilegis cancel-lats pel fracàs del servei, de manera que, finalment, el monarca i l'estament reial es reuniren a començaments de 1304 per tal de redreçar la situació.

- La reordenació i la represa del cabeçatge reial entre 13041308

Després d'haver tingut tractament e col-loqui ab los procurador e síndichs de les universitats reials, el 14 de febrer de 1304 Jaume II sancionà el retorn de les gràcies, libertats e franquees suspeses a canvi d'un nou subsidi de 150.000 s. anuals durant quatre anys, 140.000 s. per la dita ajuda i 10.000 s. per rahó dels XL mil sous qui falliren a nós del primer an, el que confirma plenament que durant la primera anualitat es pensaven col-lectar uns 140.000 s. i només se n'aplegaren $100.000 \mathrm{~s}$. Així, la suma total havia d'arribar als $700.000 \mathrm{~s}$. ja previstos inicialment en cas que l'ajuda durés cinc anys, tot i que ara hi hagué una diferència primordial, puix el rei anul.là el capítol segons el qual només podia destinar la recaptació als deutes que havia contret al regne de València ${ }^{89}$.

D'una altra banda, la fixació d'una quantitat anual exacta comportava necessàriament un altre tipus de subsidi diferent al simple cabeçatge universal. I, en bona lògica, això fa pensar que l'ajuda fou repartida en quotes entre els nuclis reials fins a completar la suma de 150.000 s. anuals, potser en base a les quantitats usualment pagades per cada universitat en les quèsties cristianes, com sembla indicar el fet que el subsidi de Gandia de l'anualitat de 1306 fos enfranquit a canvi de posar 6.000 s. en la construcció de les muralles urbanes, la mateixa quantitat que s'havia exigit a la vila en les dues quèsties anteriors que hem pogut documentar ${ }^{90}$. De fet, si prenem com a base la petició de quèstia de 1303, podem constatar que la suma total demanada en inici -sense les remissions posteriors- era de 106.000 s., als quals caldria afegir la quantitat de la ciutat franca de València, que podrien ser, doncs, uns $44.000 \mathrm{~s}$. Amb tot, també és raonable pensar que tal vegada les quotes foren

de València: E. GonZÁlez HurTebise, Libros de la tesorería de la Casa Real de Aragón, Barcelona, 1911, docs. 1339-1341, 1343, 1353, 1354, 1367, 1368, 1375, 1380, 1391, 1384, 1390, 1392 i 1399.

89 ACA, C, reg. 325, f. 87rv (14-II-1304).

90 Es tracta de les quèsties de 1297 i de 1303: ACA, C, reg. reg. 324, f. 234r (5-V-1297); reg. 333, f. 130v (29-IX-1303). 
ajustades a les sumes recaptades en cada lloc mitjançant el recent cabeçatge de 1302, que desconeixem, per la qual cosa és impossible realitzar càlculs fiables en aquest sentit.

Fos com fos, el que queda clar és que també era necessari un canvi en la forma impositiva aplicada per tal de superar les mancances del cabeçatge imposat el primer any i poder recaptar així la probable quota establerta a cada nucli a partir de 1304. Tanmateix, tampoc hem pogut trobar cap referència explícita sobre aquesta qüestió i les informacions indirectes que hem localitzat no ho esclareixen, ja que, d'un costat, apunten a la possible repetició d'un impost de capitació, mentre, d'un altre costat, indiquen, simultàniament, la utilització de mètodes impositius de repartició, proporcionals als patrimonis unifamiliars.

En el primer cas, el fet que el subsidi continués rebent entre 1304 i 1308 el nom de «cabeçatge», així com que es traspassassen als col-lectors de 1304 els llibres de 1302 que contenien les llistes de persones de cada vila per tal que $a b$ aquests libres sien mils certifficats de la cullita que han a fer ${ }^{91}$, sembla indicar que l'impost es continuava pagant individualment per caps. Així mateix, una reclamació al monarca de Bernat de Ginebret a Gandia també assenyala que el subsidi requeia directament sobre cada persona. En concret, com ja hem dit, Jaume II havia enfranquit els homes de Gandia de prestar el cabeçatge en 1306 a canvi de contribuir amb 6.000 s. en l'obra de les muralles i, per això, la universitat procedí a recaptar una exacció proporcional als patrimonis de cada possessor de la vila, tot compel-lint Ginebret a pagar la part que li corresponia en aquella quantitat per les possessions que tenia a Gandia i el seu terme. Amb tot, Ginebret ja havia pagat el cabeçatge in civitate Valencie simul cum aliis civitis Valencie, i, per tant, el rei ordenà que no estava obligat a contribuir en l'exacció substitutòria del cabeçatge a Gandia, puix ja havia satisfet aquell impost en una altra ciutat: sicque ulterius ad ipsum cabeçagium exsolvendum alibi cogi non debant ${ }^{92}$. En conseqüència, això apuntaria al fet que el nou subsidi de 1304-1308 continuà recaptant-se mitjançant un impost unipersonal de capitació, puix el seu pagament en un lloc eximia totalment de la contribució en un altre nucli.

No obstant això, també hi ha constància de l'aplicació de repartiments realitzats entre els veïns de cada vila en funció del patrimoni posseit, si més no per tal de completar la quantitat pertinent als veïns que no podien contribuir per la seua pobresa. Així, a finals de 1306 Jaume II resolgué un contenciós entre la universitat de Morella i les seues aldees super solvendiis

91 ACA, RP, MR, Llibres de notaments comuns, 774, f. 39r.

92 ACA, C, reg. 325, f. 95rv (7-XII-1306). 
nichils cabeçagii, bo i proveint que els homes de la vila pagassen per les heretats que tenien en les aldees racione ipsorum hereditatum in nichils aldearum per solidum et libram i, viceversa, que els homes de les aldees pagassen per les heretats que tenien en el terme particular de la vila pro ipsis hereditatibus in nichils ville predicte per solidum et libram ${ }^{93}$. I, en aquest sentit, podem pensar que aquell procediment, com que era efectivament desenvolupat per recaptar la part dels nichils, també podia ser aplicat per tal d'arribar a la xifra fixada per les quotes de cada universitat, tot complementant-se amb el pagament d'l s. per persona.

D'aquesta forma, seria factible que, una vegada satisfet el cabeçatge d'l s., la quantitat que mancava fins a completar la quota vilatana fos repartida proporcionalment per sou i per lliura entre els contribuents aveïnats en la població corresponent, de manera que poguessen ser superades les mancances de l'ajuda del primer any, tot reunint els 150.000 s. anuals establerts per al conjunt del reialenc. I, en relació amb això, si el cabeçatge universal havia comportant uns 100.000 s., sabem que aquesta quantitat representava dos terços del total a recaptar, per la qual cosa podem suposar que potser, en termes generals, un terç del subsidi hagué de ser reunit mitjançant un impost de repartició proporcional al patrimoni. Val a dir, per exemple, si la quota de Gandia era de 6.000 s., és possible que el primer any s'haguessen aplegat uns $4.000 \mathrm{~s}$. amb el pagament directe d'1 s. per part d'uns 4.000 habitants, mentre que, en la represa del subsidi, s'hi afegiren $2.000 \mathrm{~s}$. recaptats proporcionalment als béns d'aquells veïns. Amb tot, ens movem en el simple terreny de l'elucubració, ja que, d'una banda, el cas de cada universitat seria segurament particular, i, d'una altra banda, no disposem de dades concretes que puguen corroborar aquesta hipòtesi.

En qualsevol cas, segons el que acabem d'exposar, pensem que tal vegada la forma impositiva emprada per tal de recaptar l'auxili de 1304 a 1308 combinà la capitació i la repartició en base al patrimoni, de forma similar al que passava amb altres exaccions que rebien el mateix nom, com ara els cabezajes dels jueus aragonesos o el cabeçatge acordat com a donatiu de les Corts catalanes de $1323^{94}$. De fet, en aquest darrer subsidi totes les persones habitants al reialenc també havien de pagar $12 \mathrm{~d}$. per cap de forma universal i, ultra això, se'ls taxà una quantitat pels béns posseïts -en aquest cas, segons una escala fixada en els capítols del donatiu.

93 ACA, C, reg. 325, f. 95v (7-XII-1306).

94 M.A. Motis, Ordinaciones de la alcabala de la aljama judía de Huesca, Saragossa, 1990; M. SÁNCHEZ MARTínez i P. OrTí (eds.), Corts, parlaments i fiscalitat a Catalunya, cit., doc. V (3-XI-1323). 
Altrament, pel que fa als llocs sotmesos al pagament del subsidi valencià, la reordenació de 1304 indicava que havien de contribuir tots aquells locs que en lo primer an foren scrits, el que establia una continuitat directa amb el servei de Corts aprovat pel braç reial en $1302^{95}$. En aquest sentit, ja hem vist que el mestre racional lliurà als diputats de 1304 els llibres de la collecta del cabeçatge d'aquell primer any, i, efectivament, observem que fins i tot en el cas d'Alcalà, posseïda per infeudació pel cavaller Ponç Guillem de Vilafranca, es continuà requerint-ne la contribució ${ }^{96}$. Així mateix, Jaume II ordenà expressament al batlle general del regne que permetés continuar recaptant l'auxili entre els jueus i els musulmans, ja que no hi havia causa perquè aquells poguessen ad hoc racionabiliter excusari ${ }^{97}$. Contràriament, els llocs eclesiàstics -com havia passat des d'un principi- i també la resta de nobiliaris -com s'explicitava en la carta de represa del servei- quedaren exclosos del pagament de la nova ajuda ${ }^{98}$.

Quant a la gestió de la col-lecta, novament foren habilitades comissions anuals de diputats triats per la ciutat de València i, alternativament, per les quatre principals viles del regne. El primer any de 1304-1305 foren ordenats collidors e reebedors del dit cabessatge Ponç de Soler i Ramon de Poblet, ciutadans de València, Tomàs Vives de Canyamàs, de Morvedre, i Gonçal de Santacreu, veí d'Alzira. En el de 1305-1306 foren nomenats Pere de Ripoll i Arnau Safont per València, Domingo de Vinatea per Morella i Bernat Sanç per Xàtiva. Per a 1306-1307 foren escollits Guillem Mir i Bino Giandoni a València, Bernat Barrot a Morvedre i Pasqual Marçó a Alzira. I, finalment, en la darrera anualitat de 1307-1308 foren col-lectors Bernat Ponç i Guillem Celolm per València, Arnau Aster per Morella i Guillem Desbosc per Xàtiva ${ }^{99}$.

Sabem també a ciència certa que els triats pel Consell municipal de València pertanyien al grup de prohoms ciutadans que dirigien els afers de la

95 ACA, C, reg. 325, f. 87rv (14-II-1304).

96 ACA, C, reg. 325, f. 94v (3-IX-1306): El rei ordenà al procurador del regne que compel-lís Ponç Guillem de Vilafranca a pagar pel seu lloc d'Alcalà si havia contribuït en les anteriors anualitats, com al-legaven els prohoms i la universitat de València.

97 ACA, C, reg. 325, f. 89r (10-V-1304).

98 Sobre els llocs eclesiàstics ja hem explicat anteriorment els casos de Villores i de Beniparrell. Pel que fa als nobiliaris coneixem, per exemple, la prohibició reial feta en 1306 d'exigir diners als homes de Berenguer Dalmau, qui era senyor d'Orpesa i havia contribuït en el primer cabeçatge de 1302, pero ara no ho havia de fer en haver estat nomenat cavaller recentment; així mateix, en 1304 el monarca ordenà que no es compel-lira als homes de Beniopa, del rais de Crevillent, bo i argumentant que els habitants dels llocs que tenent nobiles vel milites, ut dictum est, in predicto auxilio contribuerit minime teneantur: ACA, C, reg. 325, f. 89v (20-V-1304), 90r (8-VII-1304) i 94v (3-IX-1306); Cartes reials, Jaume II, núm. 2059 (19-V-1304).

99 ACA, RP, MR, Llibres d'albarans, 622, f. 101v. 
urbs: Ramon de Poblet, Bino Giandoni i Guillem Celolm foren consellers de la ciutat per aquelles dates ${ }^{100}$; Ponç de Soler fou batlle de la reina i senyor de l'alqueria de Benicarló ${ }^{101}$; Pere de Ripoll també posseí alqueries, fou lloctinent del procurador enllà Xúquer i exercí com a conseller de la ciutat ${ }^{102}$; Arnau Safont tenia terres a Burjassot, en 1292 jurà Jaume II com a rei en qualitat de jurat de la ciutat, i posteriorment fou justícia de València ${ }^{103}$; finalment, Guillem Mir també va jurar el rei, fou conseller i jurat, i posseí terres i rendes prop de la capital ${ }^{104}$. Ultra això, els trobem a tots plegats, incloent un collector del cabeçatge de 1302 com Bernat Desclapers i altres personatges de l'entorn reial com Guillem Escrivà o Bartomeu Matoses, en diversos negocis conjunts que tenien el monarca com a principal client ${ }^{105}$.

Així mateix, també podem deduir que els diputats escollits a les altres viles provenien dels grups de poder urbans: Tomàs Vives de Canyamàs posseïa terres i rendes a Morvedre i a Gilet, havia estat justícia de la vila i pertanyia a l'oligarquia de la zona -Bernat Vives fou un dels dos síndics de la vila en el jurament reial de 1292106; Domingo de Vinatea havia estat batlle de Morella i comprador de rendes de la vila ${ }^{107}$; Guillem Desbosc, veí de Xàtiva, procedia

100 V. ANYÓ, El primer 'Manual de Consells' de la ciutat de València, cit.

101 ACA, RP, MR, Llibres d'albarans, 624, f. 171r (batlle de la reina); i ACA, C, reg. 200, f. 200 (compra de Benicarló).

102 E. Olmos, Inventario de los pergaminos del Archivo de la Catedral de Valencia, cit., doc. 1336; i J.V. CABEZUELO, Poder público y administración territorial en el reino de Valencia, cit., doc. 59 (20-IV-1309).

103 V. ANYÓ, El primer 'Manual de Consells' de la ciutat de València, cit.; i E. Olmos, Inventario de los pergaminos del Archivo de la Catedral de Valencia, cit., doc. 1414 (terres a Burjassot).

104 V. ANYÓ, El primer 'Manual de Consells' de la ciutat de València, cit.; i E. Olmos, Inventario de los pergaminos del Archivo de la Catedral de Valencia, cit., doc. 874 (venda de cens sobre unes cases de València), 1560 (venda de censos a Guillem Desbosc, un dels col-lectors del cabeçatge de Xàtiva), 1832-1833 (venda de terres de l'horta de València) i 1873-1874 (venda de cases prop del Túria).

105 ACA, RP, MR, Llibres d'albarans, 622, f. 127r (deute reial de 12.050 s. per raó de cinc captius comprats a Arnau Safont, Ramon de Poblet, Guillem Celolm, Bernat Fontanet i Bernat Desclapers); C, reg. 294, f. 167r (14-II-1304) (deute reial de $9.512 \mathrm{s.}$ amb Bartomeu Badia per 790 cafissos d'ordi a mesura de València, pels quals estaven obligats Bernat de Llibià, Guillem de Soler, Guillem Escrivà, Arnau Safont, Pere Mir, Bernat Desclapers, Pere de Ripoll, Ponç de Soler, Ramon de Poblet, Ramon Guillem Català, Bernat Marc i Bernat Colom).

106 E. Olmos, Inventario de los pergaminos del Archivo de la Catedral de Valencia, cit., docs. 1001, 1290, 1295, 1297, 1397, 1315 a 1318, 1324, 1341 (compravendes a la zona de Morvedre); R. GALlofRÉ, Documentos del reinado de Alfonso III de Aragón relativos al antiguo reino de Valencia y contenidos en los registros de la Corona de Aragón, València, 1968,doc. 1904 (justícia de Morvedre); ACA, C, reg. 55, f. 56r-58r (jurament de 1292).

107 R. GALlOFRÉ, Ibidem, doc. 134 (batlle) i 139 (rendes). 
igualment d'un llinatge important a la regió, amb terres i rendes a la zona i altres llocs del regne $e^{108}$; o, per exemple, Bernat Sanç havia estat jurat de Xàtiva i majordom del seu castell per aquelles mateixes dates ${ }^{109}$.

Per tant, la recaptació del subsidi continuà en mans dels grups dirigents dels principals nuclis urbans del regne, però, ara, amb la particularitat que el tresorer del rei exercí sobre els seus moviments un ferri control, ja que fou ordenat com a responsable màxim de l'ajuda. Per tant, substituint la relació directa entre els diputats i el monarca del primer cabeçatge de 1302, el tresorer reial fou a partir de 1304 qui supervisà la gestió de les comissions, ingressà els diners de l'auxili i els distribuí en funció de les assignacions ordenades per Jaume II, segons es desprèn de diversos documents continguts als registres Thesaurarii de la cancelleria: dicte auxili ab universitatibus, civitatis et regni Valencie respondeatur esseque deliberentur et tradentur nostro thesaurario ${ }^{110}$.

D’aquesta forma, el mateix dia en què es féu pública la reordenació del subsidi, el tresorer Pere Boill constituí dos procuradors, tots dos canvistes de València, ad recipiendum loco et nomino suo totam medietatem quantitatum, això és, Bartomeu Ciriol, que havia de rebre una meitat del total, i Bernat Planell, que havia de rebre'n l'altra ${ }^{111}$. Per tant, és probable que aquests dos canvistes financiassen els deutes i negocis del monarca al regne de València, com sembla confirmar el fet que en diverses ocasions els diputats foren amonestats per la seua lentitud a l'hora de recaptar el subsidi, sota l'amenaça de pagar personalment els interessos dels préstecs que hagués de sufragar el tresorer per no poder comptar amb els diners corresponents en els terminis previstos $^{112}$.

D'altra banda, com ja havia passat immediatament després de l'aprovació del donatiu de 1302, també ara el subsidi fou objecte de nombroses assignacions per part de Jaume II, les quals quedaren recollides en aquesta

108 E. Olmos, Inventario de los pergaminos del Archivo de la Catedral de Valencia, cit., docs. $578,579,581,582,589,628,756,1448$ i 1560 (compres i establiment de terres i censos en l'Alcúdia i a religiosos i ciutadans de València).

109 ACA, RP, MR, Llibres de notaments comuns, 774, f. 1r

110 ACA, C, reg. 294, f. 164r (14-II-1304). A més a més, en el retiment de comptes dels col-lectors del subsidi apareix explícitament aquest control del tresorer; així s'observa en la petita part del cabeçatge que havia de recaptar el porter Arnau Cortit en 1305-1306, de la qual devíets respondre a mi-Pere Boill-, lavors thresorer del dit senyor (ACA, RP, MR, 622, f. 52v-53r) o en el destí de la quantitat recaptada pels diputats de 1306-1307: en partida a mi, que en aquell temps era thresorer del seynor rey, e en partida a.n Pere March, ara thresorer del dit seynor (ACA, RP, MR, Llibres d'albarans, 622, f. 122r).

111 ACA, C, reg. 294, f. 163v-164r (14-II-1304).

112 ACA, C, reg. 325, f. 90v-91r (24-X-1304) i 92rv (7-IV-1305). 
ocasió -en consonància amb el que acabem de dir- no en el «registre del cabeçatge», sinó en els registres d'ordres reials adreçades al tresorer. Així, sabem que les primeres consignacions foren moltes i variades: el mateix canvista Bernat Planell en rebé dues de 15.000 s., una per una obligació que el rei li havia fet per pagar unes vistes a l'Aragó amb els magnats del regne de Castella, i una altra per aquell deute pendent de 110.000 s. que ja apareixia en les assignacions del primer cabeçatge; al ciutadà valencià Arnau Safont -un dels collectors de l'any següent-se li assignaren 30 unces d'or degudes per l'expedició a Sicília i 1.100 s. per un cavall que hi havia perdut; al conseller reial Tomàs de Pròixida 211 florins d'or, 5 tarins sicilians i 5.125 s.; a Arnau Escrivà 2 tarins i 15 grans sicilians, 47.743 s. que li mancaven d'un préstec de $48.000 \mathrm{~s}$ fet al rei, a raó de $10.000 \mathrm{~s}$. assignats en els tres primers anys del subsidi i 17.743 s. en el quart; a Ferrer Matoses, ciutadà de València, 1.000 s.j. per la pèrdua d'un cavall a la frontera amb Castella; 10.000 s. als frares de Poblet dels 50.000 s. que el rei els havia assignat sobre les exaccions del regne de València; $2.000 \mathrm{~s}$. al convent de caputxins de Xàtiva, a raó de 500 s. a l'any per un deute de 6.000 s. arrossegat des d'època de Jaume I; 9.512 s. a Bartomeu Badia, habitant de Sueca, per 790 cafissos d'ordi a mesura de València que havien comprat el batlle i l'escrivà de ració del regne; $6.000 \mathrm{~s}$. a Roderic de Biscarra per la seua quitació, cavalls i retenció dels castells de Cartagena, Callosa i Alfama; i també 5.000 s. dels 15.000 s. que se li devien a Pedro de Monteagudo, llavors procurador del regne de Múrcia, per una heretat seua a l'horta murciana que havia estat donada pel rei a Pedro López de Ayala ${ }^{113}$.

En total, onze assignacions diferents per un valor de 116.480 s., 1.000 s.j., 30 unces d'or, 211 florins d'or, 7 tarins i 15 grans sicilians, encara que desconeixem si foren efectivament pagades amb posterioritat, ja que es tractava únicament d'ordres, potser no acomplertes en la seua totalitat, com hem vist que passava amb les realitzades sobre el cabeçatge de $1302^{114}$. Aquest dubte només podria ser resolt mitjançant la consulta de la informació continguda als llibres de dates i rebudes del tresorer reial, conservats per a aquest període, però que actualment resten fora de consulta pel seu mal estat de conservació. Per tant, encara que comptàrem amb totes les assignacions teòriques no podríem conèixer de moment el destí final de la recaptació, per la qual cosa no hem procedit al buidatge sistemàtic de la sèrie Thesaurarii

113 ACA, C, reg. 294, f. 164r-167v (totes de 14-II-1304 i la darrera de 15-II-1304).

114 Així mateix, per exemple, sabem que l'assignació de $9.512 \mathrm{~s}$. Bartomeu Badia sobre el cabeçatge valencià reordenat només es complí parcialment: ACA, RP, MR, Llibres d'albarans, 622, f. 135v. 
de cancelleria, que probablement contindrà la resta d'assignacions ordenades sobre el subsidi de 1304-1308 ${ }^{115}$.

No obstant això, a través de la documentació del mestre racional sí que hem pogut conèixer alguns pagaments dispersos, abatuts en albarans debitoris de cavallers i oficials reials. Així, per exemple, sabem que: el ja esmentat Bernat Sanç, col-lector del cabeçatge en 1305-1306, va rebre 6.000 s. dels diners del subsidi durant la primera anualitat per reparar els murs del castell de Xàtiva; Pedro Jordán de Botorrita i Guillem del Cano 1.500 s. i 364 s. respectivament de la taula de Bernat Planell; i Guillem Escrivà, reboster reial, i Pere de Ribalta, ciutadà de València, dos muntants de 10.000 s., un en 1304-1305 i un altre en 1306-1307, per pagar encara els homes de la mar que foren en Sicília, això que a ells era degut per lur sou ${ }^{116}$.

En relació amb tot això, com hem explicat anteriorment, sabem que Jaume II es lliurà en la reordenació del subsidi de l'obligació de destinar la recaptació als deutes del regne de València, reservant-se el dret de distribuir, e pagar aquella, e fer d'aquella nostra voluntat ${ }^{117}$. Tanmateix, cal destacar que, malgrat això, totes les assignacions que hem documentat estaven relacionades amb pagaments pendents a creditors naturals, heretats o amb càrrecs al regne $e^{118}$. Per tant, sembla que la represa del servei aprovat en les Corts continuà prioritzant la satisfacció dels deutes contrets al territori valencià, encara que, més endavant, en maig de 1304 i en octubre de 1306, Jaume II ordenà destinar parts del subsidi a quibusdam negociis nostris, bo i palesant el seu dret a emprar els diners en altres qüestions ${ }^{119}$.

115 Concretament es tracta dels registres 294-297, que van des de l'any 1301 fins a 1310. 116 ACA, RP, MR, Llibres de notaments comuns, 774, f. 1r (Sanç); Llibres d'albarans, 622, f. $12 \mathrm{v}$ (Cano), 89v (Jordán de Botorrita) i 55v-56r (Escrivà i Ribalta). També podem considerar una assignació satisfeta el traspàs del cabeçatge de Benifaió i Alginet al seu senyor, el ciutadà valencià Bartomeu Matoses, pels serveis prestats: ACA, C, reg. 325, f. 93r (14-VII-1305).

117 ACA, C, reg. 325, f. 87rv (14-II-1304).

118 A banda dels que ja hem esmentat com a cavallers, ciutadans o habitants del regne, també ho eren Roderic de Biscarra, alcaid dels castells de Callosa i Oriola, Pedro Jordán de Botorrita, alcaid de Guardamar, o Arnau Escrivà i Tomàs de Pròixida, cavallers valencians. Cf.: J.R. HinojosA, Diccionario de historia medieval del Reino de Valencia, cit.

119 ACA, C, reg. 325, f. 89r (10-V-1304) i 95r (6-X-1306). En el primer cas, davant les notícies d'un possible atac musulmà al territori valencià, el rei ordenà als col-lectors, els justícies i els consells de València, Morella, Xàtiva, Morvedre i Alzira, al porter reial Bernat Ginebret i als principals prohoms urbans del regne, fer tot allò que disposés l'enviat Guillem Llobet. En desconeixem les possibles actuacions, però, si més no, sabem que a l'any següent sí que s'armaren tres galeres i un lleny, amb 30.000 s. del cabeçatge i 20.000 s. aconseguits en préstec d'alguns particulars de València, per tal de fer front als atacs dels musulmans, que llavors saquejaren la Vila-joiosa: 
Finalment, comptem amb tres dels quatre retiments de comptes realitzats davant el mestre racional pels col-lectors anuals del donatiu; concretament, els de 1304-1305, 1306-1307 i 1307-1308, mentre que la segona anualitat, de 1305-1306, va ser presentada a Bernat Rodera, els llibres d'albarans del qual, com ja hem comentat, no s'han conservat ${ }^{120}$. Certes informacions contingudes als retiments evidencien els canvis aplicats en el tipus de subsidi recaptat, com, per exemple, el fet que en aquesta ocasió, contràriament al cabeçatge de 1302 -en què s'insistia en la universalitat del pagament i només s'eximí a Castalla i Biar-, s'atorgaren nombroses franqueses a persones i universitats, el que sembla indicar, com hem dit, l'establiment de quotes vilatanes, que podien ser enfranquides o modificades parcialment amb la seguretat de realitzar previsions fiables. Així, per exemple, coneixem els enfranquiments temporals que es concediren a les viles de Montesa i Cullera o la substitució del cabeçatge de Gandia de 1306 per 6.000 s. a posar en els murs de la vila, recaptats en aquest cas mitjançant un impost proporcional al patrimoni dels veïns ${ }^{121}$. Tot plegat, les exempcions assoliren certa importància, ja que en els tres comptes que coneixem arribaren aproximadament al 20\% de la xifra total demanada.

Així, en la primera anualitat de 1304-1305, retuda en març de 1312, els col-lectors presentaren franqueses atorgades pel rei ab cartes sues a algunes viles e llocs del regne de València e algunes persones per valor de 27.160 s., quantitat de la qual s'havien de descomptar 108 s., a rahó de IIII sous per cascun mil, car axí se devia fer segons la ordenació de la dita cullita, i, per tant, la suma final pagada pels diputats fou de 122.948 s. ${ }^{122}$ Per la seua banda, en l'anualitat de 1306-1307 s'atorgaren també franqueses col-lectives i individuals, anotades en el quaern de paper que presentaren els col-lectors al mestre racional en març de 1308, per valor de 28.358 s., quantitat de la qual es descomptaren els corresponents 113 s. 5 d., així com 244 s. 8 d. que els collectors havien posat de més en el seu compte pels nichiles de Catarroja;

M. GASPAR, «Relaciones de la Corona de Aragón con los estados musulmanes de Occidente. El negocio de Ceuta entre Jaime II de Aragón y Aburribia Soleiman, sultán de Fez contra Mohamed III de Granada», Revista del Centro de Estudios Históricos de Granada, 13 (1923), p. 279-289. Pel que fa a la immobilització del cabeçatge en octubre 1306, simplement sabem que el rei ordenà apartar-ne $25.000 \mathrm{~s}$. fins que ell mateix arribés a València.

120 En el retiment de 1306-1307 es detallen els col-lectors de cada any i s'hi diu que el de l'any anterior havia estat fet davant Bernat Rodera: ACA, RP, MR, Llibres d'albarans, 622, f. $101 \mathrm{v}$.

121 ACA, C, reg. 325, f. 90r (6-VIII-1304, Montesa), 93v (29-VII-1305, Cullera), 95r (7XII-1306, Gandia).

122 ACA, RP, MR, Llibres d'albarans, 624, f. 159v. 
per tant, la xifra final retuda fou de 122.000 s. 1 d. ${ }^{123}$ En darrer terme, el retiment de comptes de l'anualitat de 1307-1308 únicament proporciona les quantitats netes: 32.893 s. 8 d. abatuts per les franqueses i, per tant, 117.106 s. 4 d. recaptats pels diputats ${ }^{124}$.

En tots els casos, doncs, les quantitats gairebé triplicaven els $41.700 \mathrm{~s}$. disponibles amb les quèsties de 1303 -l'any de suspensió del servei-, tot ascendint a uns $120.000 \mathrm{~s}$. anuals, amb els quals el rei pogué anar eixugant els deutes acumulats al regne de València o fer front a altres afers. A més, cal sumar l'exigència paral.lela d'almenys tres subsidis a les minories religioses durant aquest període, dos als jueus en desembre de 1304 i abril de 1306, per un valor de 35.000 s., i un altre de 9.900 s. als musulmans en novembre de $1306^{125}$. Pel contrari, la franquesa de quèstia, peita i redempció d'exèrcit concedida a les viles reials cristianes mentre es recaptés el donatiu sí que produí efecte, puix, de fet, l'única petició addicional que realitzà Jaume II -de pregàries a alguns nuclis del nord del regne per escometre unes vistes amb el papa a Montpeller en 1305- se saldà amb la modesta suma de 3.000 s. i la negativa directa de molts dels consells municipals a contribuir-hi, al-legant segurament aquella exempció temporal ${ }^{126}$.

En canvi, en març de 1308, en concloure la franquesa que comportava el cabeçatge de 1304, sabem que el rei demanà una nova ajuda per raó d'un viatge a les parts de França per haver vistes ab lo rey Karles, en què contribuí un grup més nombrós de viles reials amb una quantitat major ${ }^{127}$. I, finalment, al llarg de 1309 Jaume II realitzà dues peticions, una redempció d'exèrcit pel maig per afrontar la conquesta d'Almeria i una quèstia pel novembre des del mateix setge de la medina, que tornaren al camí habitual de la sol-licitud directa d'exaccions als nuclis reials fora de les assemblees parlamentàries ${ }^{128}$. En qualsevol cas, el fracassat intent de prendre Almeria formava part d'un nou episodi d'expansió territorial que posava fi a l'anterior cicle bèl-lic, progressivament tancat amb la pau de Caltabellotta de 1302, la sentència arbitral de Torrelles de 1304 i l'acord d'Elx de 1305.

123 ACA, RP, MR, Llibres d'albarans, 622, f. 122r.

124 ACA, RP, MR, Llibres d'albarans, 624, f. 191r.

125 ACA, C, reg. 333. f. 125r (20-IV-1306) i 166v (28-XII-1304), RP, MR, Llibres d'albarans, 622, f. $76 \mathrm{v}$.

126 ACA, RP, MR, Llibres d'albarans, 622, f. 87r. Arnau Cortit, porter reial, recaptà 1.000 s. de Borriana, 1.000 s. de Castelló de la Plana, 500 s. de Vila-real i 500 s. de Llíria. Tanmateix, Morella, Morvedre, Ademús, Castellfabib i Alpont no van aportar res, encara que també se'ls havia demanat.

127 La suma total recaptada ascendí a 24.000 s.: ACA, RP, MR, Llibres d'albarans, 622, f. $164 \mathrm{r}$.

128 ACA, RP, MR, Llibres d'albarans, 623, f. 89v; C, reg. 326, f. 11r-13v (8-XI-1309). 


\section{CONCLUSIONS}

Com hem vist, les campanyes dutes a terme contra el regne castellà de Múrcia i, sobretot, contra Frederic II de Sicília generaren un deute enorme per a Jaume II d'Aragó, que en tornar de manera definitiva de terres itàliques -després de quinze mesos d'absència- es veié forçat a convocar una sèrie successiva de Corts als diferents territoris peninsulars de la Corona: primer, en 1299-1300 a Catalunya, on declarà tenir pagaments pendents per valor de 6.000 .000 s., després, en 1300 i en 1301 al regne d'Aragó, on els deutes ascendien a més de 3.400.000 s.j., i, finalment, en 1301-1302 al de València, on es demanaren un mínim de 700.000 s. Per tant, un dels objectius prioritaris del Jaume II en aquelles assemblees parlamentàries fou el de trobar una via mitjançant la qual els regnes contribuïssen a sanejar les pròpies finances reials. En conseqüència, els serveis aprovats adquiriren una especial importància, com ho demostra l'assaig de formes fiscals noves i ajustades a les relacions de poder particulars de cadascuna de les entitats polítiques esmentades.

En aquest sentit, si bé en tots ells havien de contribuir tant l'estament nobiliari com el reial, quedant al marge l'eclesiàstic que ajudà al rei per altres vies, les diferències entre uns i altres foren notables. A Catalunya Jaume II decidí vendre el tribut del bovatge per 4.000 .000 s., una quantitat que es recaptà durant cinc anys, fins a 1305, a través de cises establertes als dominis afectats i gestionades per comissions mixtes de nobles i ciutadans. Al regne d'Aragó, en canvi, es pagà un impost directe associat a la compra unipersonal, universal i forçosa d'una pesa de sal per $12 \mathrm{~d}$.j. - un preu superior al del mercat- durant dos anys, fins a 1303, també gestionada per comissions interestamentals de cavallers i vilatans; amb tot, la novetat resultà un fracàs i, a banda de provocar el revifament de la Unió aragonesa, obligà a substituir la segona anualitat per un pagament simple i net de 10 d.j., encara que desconeixem el seu rendiment final. Aquest mateix camí és el que se seguí inicialment al territori valencià, on s'acordà el pagament d'un cabeçatge de 12 d., tot i que en aquest cas, segurament com a conseqüència del conflicte foral que enfrontava la noblesa i el braç reial des de 1261, el donatiu es gestionà de forma individualitzada en cadascun dels dos estaments.

Així, pel que fa als dominis nobiliaris, el cabeçatge valencià es cobrà únicament durant un any, recaptat per dos diputats del braç militar -un de llinatge aragonès i un altre català-, dels quals desconeixem la seua relació concreta amb el mestre racional, tot i que, si més no en finalitzar la recaptació, hagueren de lliurar-li els llibres de la col-lecta. Fos com fos, cal destacar que aquest sembla ser el primer donatiu que la noblesa concedí al monarca en una assemblea parlamentària valenciana $i$, malgrat la seua curta durada $i$ 
els diversos problemes documentats per a la seua posada en marxa, serví per tal de fer participar els vassalls dels nobles en el pagament dels deutes que el rei tenia amb els mateixos cavallers del regne de València ${ }^{129}$.

Per la seua banda, a les universitats reials el cabeçatge fou promès durant un màxim de cinc anys, amb l'objectiu de reunir fins a 140.000 s. anuals, recaptats per comissions de quatre diputats collectors procedents dels grups de poder urbans, dos triats per la ciutat de València i els altres dos, alternativament cada any, per les principals viles del regne (Morella, Xàtiva, Morvedre i Alzira), sota les ordres directes del monarca. Però també en aquest cas fallaren les previsions, ja que només es reuniren uns 100.000 s., i la segona anualitat, de 1303, fou reemplaçada per una quèstia ordinària, que rendí unes quantitats molt menors. Per això mateix, en 1304 el subsidi reial fou reprès per als quatre anys que restaven, ara a raó de $150.000 \mathrm{~s}$. anuals, possiblement combinant un impost de capitació amb un de repartició, de manera que se seguí cobrant fins a 1308. En aquesta segona fase de l'auxili els diputats urbans estigueren sota la supervisió del tresorer i del mestre racional, el que indica un important control de l'administració reial. En tot cas, també cal destacar que aquesta era la primera vegada que la gestió del donatiu d'una assemblea parlamentària valenciana era traspassada a comissions estamentals amb competències sobre la totalitat dels dominis reials o nobiliaris, un precedent encara llunyà dels diputats del General, perpetuats a partir de la segona meitat del segle XIV ${ }^{130}$.

Altrament, l'anàlisi de l'evolució particular del cabeçatge del braç reial proporciona interessants informacions sobre diverses qüestions. En primer lloc, la previsió de recaptar uns 140.000 s. cada any a través del pagament directe d'1 s. assenyala que els síndics urbans i la monarquia calculaven en aquella mateixa xifra, 140.000, el nombre total d'habitants del reialenc a primeries del Tres-cents. No obstant això, la col-lecta efectiva del primer any fou tan sols de $100.000 \mathrm{~s}$, el que segurament indica un alt grau d'evasió fiscal, ja que, tot i que certament

129 Anteriorment, sembla que els nobles heretats al regne de València només havien concedit a la monarquia un subsidi de 20.000 s., en 1272, a canvi de la confirmació reial de les terres que posseien en aquells moments. I aquell pagament va ser aprovat no en una assemblea exclusivament valenciana, sinó en el marc d'unes Corts generals a tota la Corona celebrades a Lleida. Cf.: V. BAYDAL, Els fonaments del pactisme valencià. Sistemes fiscals, relacions de poder i identitat col-lectiva al regne de València (c. 1250 - c. 1365), Universitat Pompeu Fabra, Tesi doctoral inèdita, 2011, tom I, p. 144-145.

130 Lúnica estimació demogràfica que coneixem per a moments anteriors o coetanis és la de Josep Torró, qui va plantejar, simplement «com a hipòtesi de treball», que tal vegada entorn de 1270 hi hauria uns 100.000 individus per al conjunt del regne: J. TORRÓ, El naixement d'una colònia. Dominació i resistència a la frontera valenciana (1238-1276), València, 2006 [1 $1^{\mathrm{a}}$ ed.: 1999], p. 100-102. 
hi pogué haver una errada en les estimacions demogràfiques, cal tenir present que es comptava amb la important ajuda de les llistes de focs dels monedatges recaptats periòdicament per l'administració reial. En qualsevol cas, el que podem afirmar a ciència certa és que les dades d'aquest cabeçatge de 1302 forneixen una forquilla d'entre 100.000 i 140.000 habitants -incloent cristians, musulmans i jueus- al reialenc, un espai que, a més a més, podem delimitar amb cert detall gràcies al coneixement dels llocs on es va cobrar l'impost ${ }^{131}$.

En un altre ordre de coses, les implicacions del fracàs de la primera anualitat del donatiu apunten a la naturalesa econòmica del pactisme valencià, en línia amb les teoritzacions molt posteriors de juristes valencians com Pere Belluga, del segle XV, o Cristòfor Crespí de Valldaura i Llorenç Mateu, del segle XVII, que el fonamentaven en lleys comprades y pagades ${ }^{132}$. Efectivament, en aquest cas la suspensió del subsidi promès en Corts pel braç reial significà la cancel-lació per part del monarca dels privilegis atorgats en l'assemblea. Alhora, però, l'interès de l'estament per recuperar-los i del rei per rebre un auxili molt més rendible que les quèsties habituals -compromeses per franqueses i assignacions prèvies-, comportà la finalització del cabeçatge entre 1304 i 1308, sota unes noves condicions que asseguraren la recaptació global d'uns 700.000 s., la quantitat que s'havia estimat des d'un principi.

D'una altra banda, malgrat que en la represa del subsidi Jaume II es reservà el dret a invertir els diners reunits en altres afers, sembla que principalment es destinaren a pagar els deutes reials contrets al regne de València. No debades aquest sanejament de deutes fou el principal motiu del monarca per a convocar un cicle successiu de Corts entre 1299 i 1302 a Catalunya, Aragó i València, dins del qual hem pogut analitzar amb detall el desconegut servei aprovat per l'assemblea valenciana. Restaria per examinar, doncs, l'altra cara de la moneda de la negociació fiscal parlamentària: les contraprestacions polítiques obtingudes pels diversos estaments en aquests actes de negociació col-lectiva amb la monarquia, les quals, sotmeses també a una anàlisi comparativa, podrien mostrar amb més nitidesa les particulars relacions de poder a cada regne i ajudar a discernir la naturalesa diversa dels sistemes pactistes $\mathrm{i}$ fiscals de cada unitat política de la Corona d'Aragó ${ }^{133}$.

131 Anteriorment, dos subsidis aprovats en assemblees parlamentàries, els de 1271 i 1284, comptaren amb la participació de prohoms locals per recaptar-los, però en col-laboració amb els oficials reials i sense l'autonomia necessària per tal de controlar globalment el conjunt del reialenc: Ibidem, tom I, p. 140-144 i 207-211.

132 J. LALINDE, «El pactismo en los reinos de Aragón y de Valencia», dins de L. LEGAZ et alii, El pactismo en la historia de España, Madrid, 1980, p. 111-139.

133 Lanàlisi d'un altre cicle de Corts proper en el temps, el de 1291-1292, ens ha servit per a discernir algunes d'aquelles diferències territorials: V. BAYDAL, "'Que 


\section{APÈNDIX DOCUMENTAL}

\section{DOCUMENT 1}

1302, gener, 24. València

Jaume II, rei d'Aragó, reconeix als homes de la ciutat, les viles i llocs del regne de València que aquests, en les recents Corts celebrades a la capital, li han concedit, de gràcia i sense crear precedent impositiu, que tots els homes i dones habitants al reialenc -de la llei i condició que siguen, cristians, jueus o musulmans, i independentment de l'edat que tinguen- pagaran 12 diners reials de València cada any durant les quatre anualitats següents per tal de pagar els deutes reials. En cas que el termini de quatre anys no siga suficient per pagar els deutes que el monarca té a la ciutat i regne de València, l'ajuda s'allargarà un any més.

\section{B: ACA, C, reg. 199, f. 44r}

Noverint universi quod nos, Iacobus et cetera, recognoscimus vobis, iuratis, probis hominibus et universitati civitatis Valencie necnon universis et singulis hominibus villarum et aliorum locorum in regno Valencie constitutorum, et universis hominibus in dicto regno habitantibus, cuiuscumque legis et condicionis sitis, quod nunc in Curia generali quem vobis celebravimus in civitate Valencie concessistis et dedistis nobis de gracia in auxilium solvendorum debitorum nostrorum quod quilibet homo et femina, cuiuscumque legis et condicionis sit, christianus, iudeus et sarracenus, habitatores dicte civitatis et villarum seu locorum dicti regni qui sunt nostri vel hominum nostrorum vel quorumcumque aliorum locorum de realencho, cuiuscumque etatis sint ex quo nati fuerint et inventi extiterint tempori, quo, iuxta ordenacionem dicte Curie scribentur, solvant vel solvi debeant pro eis duodecim denarios regalium Valencie pro quoquo eorum quolibet anno hinc ad quatuor annos primos venturos et continue numerandos, ita quod si transactis dictis quatuor annis, denarii qui ibi collecti et soluti fuerint sub forma premissa non sufficerent ad solucionem debitorum nostrorum que debemus in civitate et regno Valencie, quod dictum auxilium duret per unum annum ultra, sic quod sint quinque anni computandi a prima die presentis mensis ianuarii in anno quousque completi sint dicti quinque anni.

Et promitimus vobis et vestris, per nos et nostros successores, quod, transacto tempori concessionis predicte nobis per vos nunc liberaliter facte,

vengués a emparar et reebre los dits regnes e terres sues'. La naturaleza diversa de los pactismos territoriales de la Corona de Aragón a la llegada al trono de Jaime II (1291-1293)», Actas IV Simposio Internacional de Jóvenes Medievalistas. Lorca, Múrcia, 2009, p. 27-38. 
nunquam nos nec successores nostri possumus exigere nec petere neque exigemus aut petemus a vobis vel successoribus vestris racione presentis concessionis sive subsidii similem adiutam sive subsidium nec istud possimus in usum vel consuetudinem allegare vel nullo modo ipsam ulterius vobis imponere servitutem. Volumus etiam et concedimus vobis quod, finito tempore dicti subsidii seu adiute, vestris privilegiis et libertatibus ac franquitatibus per eandem adiutam vel prestacionem ipsius nullum periudicium generetur, sed in eo statu et firmitate quibus nunc sunt maneant et prout nunc vobis tunc similiter observentur. Et, ad maiorem firmitatem, iuramus per Deum et eius sancta IIII ${ }^{\text {or }}$ evangelia, manibus nostris corporaliter tacta, predicta attendere et nunquam contravenire aliqua racione.

In cuius rei testimonium presentem cartam nostram sigillo nostro appendicis iussimus roborari.

Datum ut supra.

\section{DOCUMENT 2}

1304, febrer, 14, València

Jaume II, rei d'Aragó, torna els privilegis que havia atorgat als habitants del regne de València en les recents Corts, els quals havien estat suspesos a causa del baix rendiment de l'ajuda concedida per la ciutat i les viles del regne. Ho fa després d'haver celebrat col.loqui amb els síndics i procuradors municipals i establir que havien de donar 150.000 sous durant quatre anys a partir de febrer de 1304, 140.000 sous per l'ajuda concedida en principi i 10.000 sous pels 40.000 que van faltar el primer any. En aquesta contribució han de participar tots aquells llocs de reialenc als quals s'havia demanat inicialment l'ajuda i, a més a més, se’ls restitueix la franquesa d'host concedida a canvi. No obstant això, en contrast amb l'ajuda inicial, en què els diners recaptats havien de ser destinats als deutes del regne, ara el monarca es reserva el dret de distribuir-los lliurement.

B: ACA, C, reg. 325, f. 87rv

Edit. per: L. AlANYÀ, Aureum Opus regalium privilegiorum civitatis et regni Valencie, València, 1515, «Iacobi secundi», XI.

En nom de nostre Senyor. Sàpien tots qui la present carta veuran que nós don Jacme, per la gràcia de Déu rey d'Aragó etcètera, entenens a pau e a justícia e a bon estament del regne de València aguéssem en l'an passat manada e celebrada Cort general en la ciutat de València a prelatz, religiosos, richs hòmens, cavallers, ciutadans e hòmens de viles del dit regne, e a suplicació 
lur aguéssem atorgades a les universitats de la dita ciutat e viles nostres del regne damunt dit gràcies e libertates e franquehes, segons que per los capítols ordenats en la dita Cort e per privilegis nostres clarament apar. Et en aquella matexa Cort les dites universitats de la ciutat e de les viles aguéssen a nós atorgada ajuda per pagar nostres deutes sots la forma en la dita Cort ordenada, la qual ajuda crèyem nós, e les dites universitats se pensaven, que pujàs a major quantitat que no fo, segons que aparech per lo nombre d'aquella en lo primer an damunt dit qui passat és, et per aquesta rahó nós aguéssem sotspeses les dites gràcies, libertates e franquehes.

A la per fi, nós estant personalment en la ciutat de València, comparegren denant nós síndics e procuradors, axí de la ciutat com de les viles del dit regne, humilment supplicans a la nostra reals magestat que en lo feit damunt dit deguéssem provehir a bon estament e tranquil-litat de la ciutat e del regne e a profit dels sotsmeses. Et enaxí, nós, esguardans que a nós se pertayn e al nostre offici de constituyr e de posar nostres gents en bon estament e ésser favorables e benignes a aquelles coses que esguarden comuna utilitat, aguem sobre aquestes coses tractament e col-loqui ab los procurador e síndichs damunt dits. Et finalment fo axí atorgat a nós per ells que les dites universitats de la ciutat e de les viles del regne daran a nos per la ajuda damunt dita que promesa nos fo en la dita Cort CL mil sous de reals per cascun an per IIII ans ara esdevenidors, en aquesta manera, ço és, CXL mil sous per la dita ajuda e $\mathrm{X}$ mil sous per rahó dels XL mil sous qui falliren a nós del primer an, e axí seran en suma cascun an CL mil sous. Et que adés de present en lo mes de febrer començen a ésser e acórrer los dits IIII ans contínuament.

Sie entès, emperò, que en los dits CL mil sous sien tenguts pagar tots aquells locs que en lo primer an foren escrits et que la dita ajuda en lo mes de febrer damunt dit se començ a escriure e sie cullida quant a la ciutat al dia de sent Johan, et quant a les viles que.s començ a scriure adés de present en lo dit mes e que sie cullida a la festa de sent Michel. Et aquesta cullita d'aquest an axí feita en aprés cascun ayn, axí en la ciutat com en les viles, sie la dita ajuda escrita en lo mes de febrer e cullida en la festa de sent Johan per los III ans següents. E jaçsie ço que en la Cort fos ordenat capítol que nós fóssem tenguts de pagar la dita ajuda als deutes del regne, que, no contrastant lo dit capítol, que nós puscam distribuir e pagar aquella, e fer d'aquella nostra voluntat. En aquesta, emperò, ajuda no són enteses los locs dels cavallers. Encara que nós prenguem en compte les messions que.s covenran a fer en cullir e plegar la dita ajuda, segons que en la Cort damunt dita fo ordenat e.s seguí en lo primer an. Encara que nós servem e façam servar als ciutadans e a aquells de les viles del regne tot ço que en la Cort damunt dita e per aquella 
fo per nos atorgat e ordenat. Encara que.l capítol temporal de les hosts qui fo feyt e ordenat en la Cort damunt dita sie observat, açò enadit que y sie entesa la terra del noble en Johan Emanuel, axí com los regnes de València e de Múrçia, estant emperò salvu lo privilegi de la ciutat.

On nós, en Jacme, per la gràcia de Déu rey damunt dit, volén nós aver benignament e favorable ab nostres sotsmeses, de certa sciència, per nós e per los nostres presents e esdevenidors, avens nós per pagatz de la ajuda damunt dita axí com ara noveylament nos és atorgada en la forma et en les maneres damunt dites, donam e atorgam e aprovam a vós, tots e sengles ciutadans e habitadors de la ciutat damunt dita de València, e als vehïns e habitadors del regne mateix, presents e esdevenidors per tots temps, que us servarem e servar-vos farem tot ço que en la dita Cort e per aquella vos fo per nós atorgat e ordenat, e de totes aquelles e sengles puscats usar vós e els vostres liurament e francha, segons que pus planerament en la dita Cort fo ordenat e atorgat, manans per la present carta nostra a procuradors, veguers, batles, justícies, sobrejuncters, çalmedines, jurats e a tots altres officials e sotsmeses nostres, presents e esdevenidors, que totes aquestes coses e sengles tenguen e observen, e tenir fassen e observar, e no y venguen contra ne hi jaquesquen contravenir nuyl hom.

Datum Valencie, $X V I^{\circ}$ kalendas marcii, anno Domini M CCC III.

\section{DOCUMENT 3}

Anotació pendent de 1304 del mestre racional Pere Boïl traslladada en un llibre de notaments confeccionat en 1338. Els llibres de la col-lecta del cabeçatge del regne de València de 1302 són tramesos a Ponç de Soler i Ramon de Poblet, col.lectors del cabeçatge de 1304, per tal que certifiquen millor la nova col.lecta. Deuen tornar els llibres quan acaben -però no ho van fer i no es va cancel-lar l'anotació.

B: ACA, RP, MR, Llibres de notaments comuns, 774, f. 39r

Ponç dez Soler, Ramon de Poblet

Primerament dels libres de la cullita del cabeçatge del regne de València de l'any M CCC I, los quals trametén a.n Ponç dez Soler e a.n Ramon de Poblet, collidors de la ajuda atorgada al senyor rey en lo dit regne en l'any de M CCC III per tal que ab aquests libres sien mils certifficats de la cullita que han a fer e axí deven-los-nos tornar quant se'n sien certifficats.

Primerament lo quaern de la parròchia de sent Nicholau de la moraria de València. 
Ítem lo quaern de la parròchia de Santa Creu.

Ítem lo quaern de la parròchia de Santa Caterina.

Ítem lo quaern de la parròchia de Sent Salvador.

Ítem lo quaern de la parròchia de Sent Berthomeu.

Ítem lo quaern de la parròchia de Santa Maria.

Ítem lo quaern de la parròchia de Sent Johan.

Ítem lo quaern de la parròchia de Sent Martí.

Ítem lo quaern de la parròchia de Sent Lorenç.

Ítem lo quaern de la parròchia de Sent Estheve e de Sent Thomàs.

Ítem I quaern de la parròchia de Sent Andreu e de la juheria de València.

Ítem I libre de Xàtiva e de les alcharies, e de Montesa, e de Vaylada, e de la moraria e de la juheria de Xàtiva, e de Balbayt.

Ítem I libre de Xixena, de Penàguila, de Gallinera, de Pego, de Murla e de Dénia, e de Gandia e de Corbera.

Ítem I libre d'Algezira ab les alcharies, e dels juheus d'Algezira e dels moros d'Algezira.

Ítem I libre de Cuylera ab les alcheries e d'Elcalà de Gallinera, que és en $I^{a}$ cèdula cosida e.l libre.

Ítem I quaern d'Ademús.

Ítem altre d'Orpesa.

Ítem altre d'Almedíxer.

Ítem I quaern de Borriana, d'Uxó e d'Alfandeguella.

Ítem altre quaern de Vilafrancha.

Ítem altre d'Olocau, de Cinchtorres e de la Mata.

Ítem altre de Líria.

Ítem altre de Morvedre.

Ítem altre de Madrona.

Ítem altre de Castelló de Borriana.

Ítem altre de Palangues de Joncosa.

Ítem altre de Forcal e de Vilores.

Ítem altre de Vaylbona de Erbers, sobirans de Xiva.

Ítem altre de Castellfort, de Portell, aldeas de Morella.

Ítem altre quaern de les persones dels masos de Morella.

Ítem altre quaern de Castellhabib.

Ítem altre quaern d'Alpont.

Ítem altre quaern de Vila reyal.

Ítem altre libre de Ruçaffa ab les alcheries tro a Benifayó e tro a Guadalaviar e ab la conqa de l'Albuffera.

Ítem I quaern dellà de Godalviar. 
Ítem altre quaern de la vila de Morella.

De la cullita damunt dita reteren compte los damunt dits a.n Pere Boyl, mestre racional, e fo la cullita per tot CL mil sous, del qual compte els fo fet albarà. 